\title{
Ammonites from the Apoderoceras beds (Early Pliensbachian) in São Pedro de Muel (Lusitanian Basin, Portugal)
}

\author{
CHRISTIAN MEISTER, JEAN-LOUIS DOMMERGUES \& ROgÉRIO B. ROCHA
}

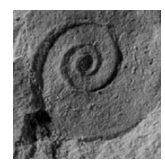

\begin{abstract}
The lowermost Portuguese Pliensbachian is characterized by the association of Apoderoceras dunrobinense Spath, Tragophylloceras numismale (Quenstedt) and Vicininodiceras aff. mouterdei Donovan. This ammonite fauna indicates the lower part of the Jamesoni Chronozone (lower to middle Taylori Subchronozone). Thanks to the numerous specimens collected, the ontogeny and variability of A. dunrobinense Spath, could also be investigated. The paleogeographical distribution of these ammonites underlines the close connections between the Lusitanian Basin and the Euroboreal seas during the Early Pliensbachian. - Key words: Lower Jurassic, ammonites, taxonomy, biostratigraphy, paleogeography, Lusitanian Basin.
\end{abstract}

\begin{abstract}
Meister, C., Dommergues, J.-L. \& RochA, R.B. 2012. Ammonites from the Apoderoceras beds (Early Pliensbachian) in São Pedro de Muel (Lusitanian Basin, Portugal). Bulletin of Geosciences 87(3), 407-430 (20 figures). Czech Geological Survey, Prague. ISSN 1214-1119. Manuscript received October 7, 2011; accepted in revised form Febuary 8, 2012; published online April 17, 2012; issued September 28, 2012.

Christian Meister, Muséum d'Histoire naturelle de Genève, Département de Géologie et de Paléontologie, 1 route de Malagnou, c.p. 6434, CH-1211 Genève, Suisse; Christian.Meister@ville-ge.ch • Jean-Louis Dommergues, Université de Bourgogne, Biogeosciences, UMR CNRS 5561, 6 Boulevard Gabriel, F-21000 Dijon, France; Jean-Louis.Dommergues@u-bourgogne.fr•Rogério B. Rocha, Geological Sciences and Engineering Research Center, Earth Sciences Department, Faculty of Sciences and Technology, Universidade Nova de Lisboa, Campus de Caparica, P-2829-516 Caparica, Portugal; rbr@fct.unl.pt
\end{abstract}

São Pedro de Muel is a classical locality for the Lias of the Lusitanian Basin. The Liassic series outcrop along the coast and form thick, continuous succession quite near the more subsiding part of the basin (Fig. 1A-C). The Lusitanian Basin belongs to the Central North Atlantic domain, which at this time formed a pre-oceanic corridor with several basins more or less interconnected. It was situated between Iberica to the East and the Newfoundland area to the West (see Dommergues et al. 2010, fig. 12).

The Lias of São Pedro de Muel has been known since the works of Choffat (1880, 1885, 1903-1904) and Pompeckj (1897, 1898). Subsequently, Mouterde (1947, 1951, 1967a, b, 1970), Mouterde et al. (1981, 1983), Dommergues \& Mouterde (1980, 1981), Phelps (1985), Dommergues (1987) and, more recently, Dommergues et al. (2004a, 2004b) and Mouterde et al. (2007) have discussed the stratigraphy and systematics of the ammonite faunas from this area.

The present work focuses on the ammonites from the Sinemurian-Pliensbachian boundary beds. The aim is to describe this stage boundary, to provide new ammonite data and to complete the study of Antunes et al. (1981) and of the 'Atlas des fossiles caractéristiques du Lias portugais I et II' by Mouterde et al. (1981, 1983).

The Liassic sediments of São Pedro de Muel belongs to the Hettangian-Toarcian. In Agua de Madeiros the Upper Sinemurian series outcrops in the northern part and the Pliensbachian starts near the steps and continues to the south (Fig. 2A).

The lithological profile of Água de Madeiros is situated just under the houses of Pedra Lisa on both sides of the steps leading to the beach (praia da Pedra Lisa). The material comes from thick marly limestone and marl alternations (Fig. 2B) and includes 40 more or less well preserved ammonites. It corresponds to beds 19c, d to 19e of Antunes et al. (1981, fig. 1). These sediments belong to the Pedra Lisa Member of the upper part of the Água de Madeiros Formation (Duarte et al. 2010; Fig. 3).

Following Duarte et al. (2010) the thin bedded limestones (unit A in Fig. 3) indicate rather shallow marine environments corresponding to the end of a $2^{\text {nd }}$ order transgressive-regressive facies cycle, and the overlying limestone-marl alternations with ammonites corresponding to the beginning of a $2^{\text {nd }}$ order transgressive-regressive facies cycle. 

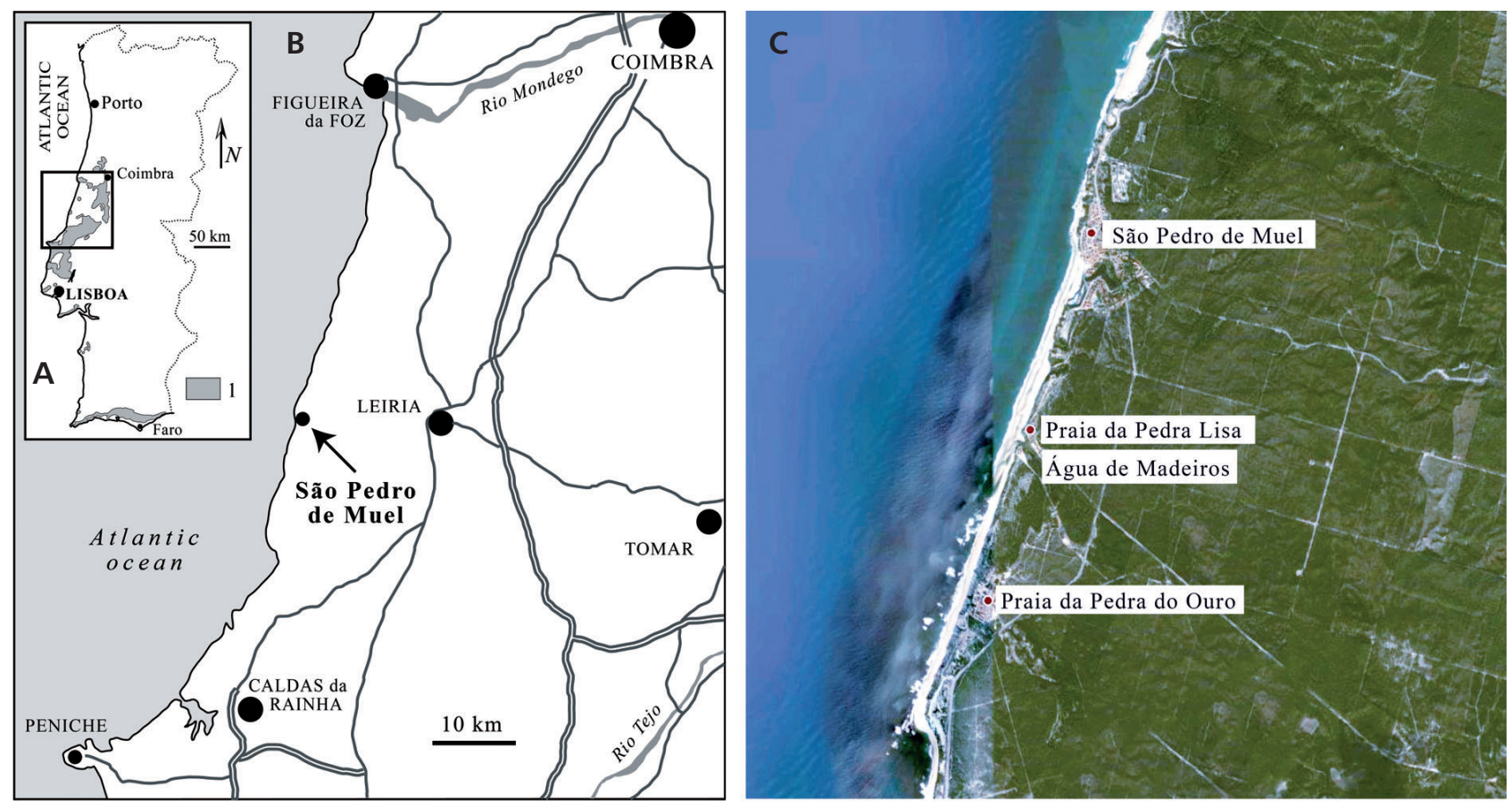

Figure 1. Maps (A, B) and satellite photograph modified from Google Earth (C) showing the studied area and the location of Água de Madeiros.
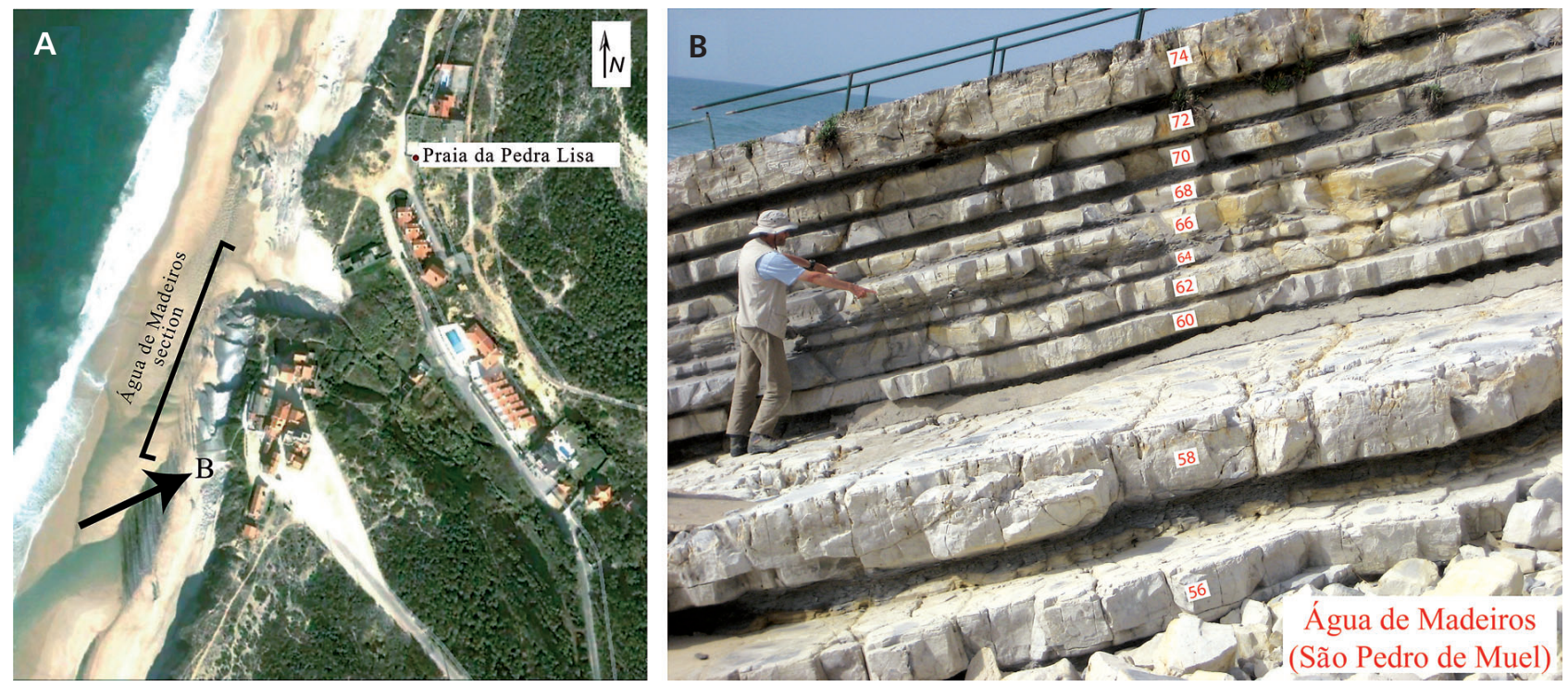

Figure 2. Location of Água de Madeiros section (A - modified from Google Earth) and detail of the upper Apoderoceras beds (B).

\section{Systematic part}

Class Cephalopoda Cuvier, 1798

Subclass Ammonoidea Zittel, 1884

Order Phylloceratida Arkell, 1950

Superfamily Phylloceratoidea Zittel, 1884

Family Juraphyllitidae Arkell, 1950

\section{Genus Tragophylloceras Hyatt, 1900}

Type species. - Ammonites numismalis Quenstedt, 1845.
Tragophylloceras numismale (Quenstedt, 1845)

Figure $4 \mathrm{C}-\mathrm{F}$

1845-49 Ammonites heterophyllus nunismalis; Quenstedt, pl. 6, figs 4a, b, 5a, b, non 3a, b et 5c.

1964 Tragophylloceras numismale (Quenstedt). - Howarth \& Donovan, pl. 48 , fig. 5 with synonymy.

1980 Tragophylloceras numismale (Quenstedt). - Schlatter, pl. 1, fig. 1.

1982 Tragophylloceras numismale (Quenstedt). - Hoffmann, pl. 1, figs 1-3. 


\section{Água de Madeiros (São Pedro de Muel)}

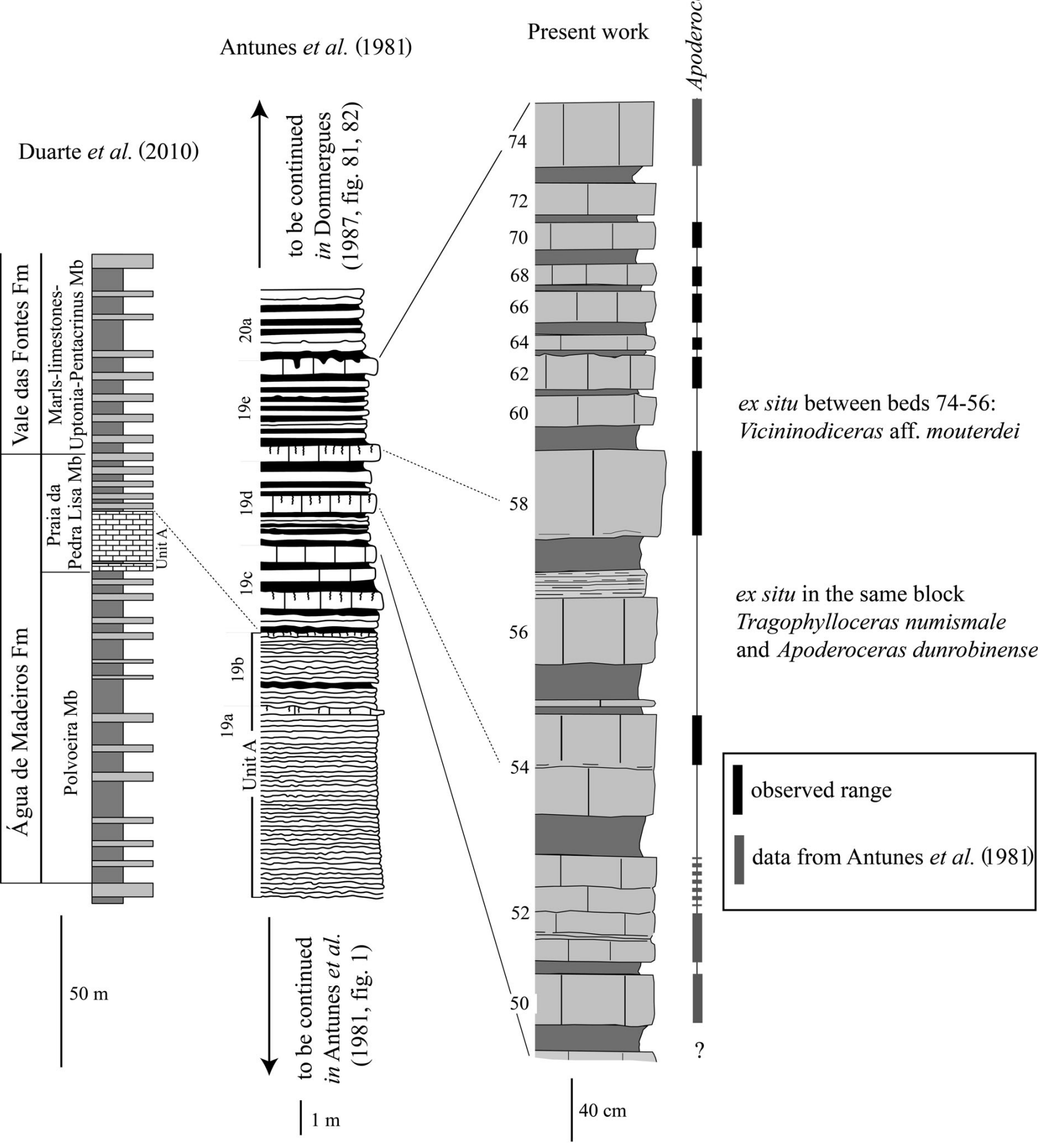

Figure 3. Água de Madeiros profile with different scales (Antunes et al. 1981, Duarte et al. 2010 and present work) with Apoderoceras range. 
1982 Tragophylloceras cf. numismale (Quenstedt). - Hoffmann, p. 129, text-fig. 18.

1986 Tragophylloceras numismale (Quenstedt). - Meister, pl. 1, fig. 5 .

1991 Tragophylloceras numismale (Quenstedt). - Schlatter, pl. 1, figs 1, 2.

non 1991 Tragophylloceras numismale (Quenstedt). - Cope, pl. 1, fig. 4; pl. 2, fig. 6 .

1992 Tragophylloceras numismale (Quenstedt). - Schlegelmilch, pl. 2, figs 1, 2

1998 Tragophylloceras numismale (Quenstedt). - Rulleau, pl. 21 , fig. 6 .

2000 Tragophylloceras numismale (Quenstedt). - Joly, pl. 2, fig. 7, 9; pl. 3, fig. 1.

2002 Tragophylloceras numismale (Quenstedt). - Howarth, pl. 1 , fig. 1 .

2003 Tragophylloceras numismale (Quenstedt). - Donovan \& Surlyk, p. 561, fig. B.

2003 Tragophylloceras cf. numismale (Quenstedt). - Donovan \& Surlyk, p. 573, figs 1-6.

2007 Tragophylloceras numismale (Quenstedt). - Schubert, pl. 1, fig. 5 .

Remarks. - Four small crushed Juraphyllitidae ( $\mathrm{D}=27 \mathrm{~mm}$ ) were found in the Apoderoceras beds. These are compressed suboxycones with a narrow umbilicus $(\mathrm{O} / \mathrm{D}=0.12)$ and fine, sinuous ribs, hardly noticeable on the flanks and more clearly expressed on the external part of the whorl where they cross the venter (Fig. 4C, E). In this species ribs on the outer part are already well expressed in the inner whorls as shown by Schlatter (1980, fig. 1). One specimen (Fig. 4D) bears some constrictions.

T. loscombi (Sowerby) is the closest form to T. numismale (Quenstedt), probably a directly derived form (Meister 1993). Sowerby's species differs by a narrower umbilicus (ibid. 1993, p. 127, fig. 4), a wider whorl section on the lower part of the flanks (more suboval) and finer ribbing, less strongly expressed on the outer part. In T. undulatum (Smith) the ribs are more developed on the flanks and rather sinuous.

Age and distribution. - T. numismale (Quenstedt) is characteristic of the Early Pliensbachian, more precisely to the Taylori Subchronozone - Valdani Subchronozone (base of Jamesoni Chronozone - base of Ibex Chronozone; see Meister 1993, Joly 2000). This species is confined to the Euroboreal regions: UK (Yorkshire, Somerset, Hebrides, Leicestershire, Gloucestershire), Denmark (Bornholm), NW and SW Germany, France (Causses, Cher, Burgundy) and Portugal (Lusitanian Basin).
Order Psiloceratida Houša, 1965

Superfamily Eoderoceratoidea Spath, 1929

Family Coeloceratidae Haug, 1910 emended Dommergues \& Meister, 1999

\section{Genus Apoderoceras S.S. Buckman, 1921}

Type species. - Apoderoceras lobulatum S.S. Buckman, 1921.

Description. - The genus Apoderoceras belongs to the family Coeloceratidae emended Dommergues \& Meister (1999). This classification has been followed by Howarth (2002), Edmunds et al. (2003) and Edmunds (2009). Previously this genus was placed in the Polymorphitidae by Schlatter (1980) and later in the Eoderoceratidae by the same author (ibid. 1991).

In the diagnosis of the Treatise (Arkell et al. 1957) Apoderoceras contains large forms, on the one hand with coeloceratomorph inner whorls becoming smooth in the adult morphology and, on the other hand more clearly ribbed forms developing spiny tubercles on the external edge. Both groups show divergent flanks and a ventral area rounded and rather flat.

The Portuguese specimens, a rather homogeneous population, belong to the second group characterized by well expressed ornamentation including the outer whorls.

Age and distribution of the genus. - UK (Yorkshire, Somerset, Dorset), Denmark (Bornholm), NW and SW Germany (Hannover area, Bade, Jura of Souabe, Württemberg), Switzerland (Jura), France [Calvados, Lyonnais (Mt d'Or) Burgundy, Gard, SW France (Aude, Quercy)], Portugal (Lusitanian Basin), Hungary (Villany, Bakony), Turkey (Pontids), USA (Alaska). This genus characterizes the lowermost part of the Pliensbachian.

Remarks. - The South American forms illustrated by Hillebrandt (1987) as Apoderoceras (Miltoceras) are true Miltoceras (Coeloceratidae) and do not belong to the genus Apoderoceras. The same is true of the Italian specimens from the Central Apennines (Venturi et al. 2005).

\section{Apoderoceras dunrobinense Spath, 1926}

Figures 4A, B, 5-14, 16A, B

1882-85 Ammonites cf. armatus nodogigas Quenstedt, pl. 25, fig. 6 .

Figure 4. Early Pliensbachian ammonites (A. dunrobinense biohorizon) from Água de Madeiros. • A, B - Apoderoceras dunrobinense Spath, 1926, form 'b' (?). B - enlargement of the innerwhorls $2 \times$. C , D, E, F - Tragophylloceras numismale (Quenstedt). Scale bar $=10 \mathrm{~mm}$. 
Christian Meister et al. • Ammonites from the Apoderoceras beds, Pliensbachian, Lusitanian Basin

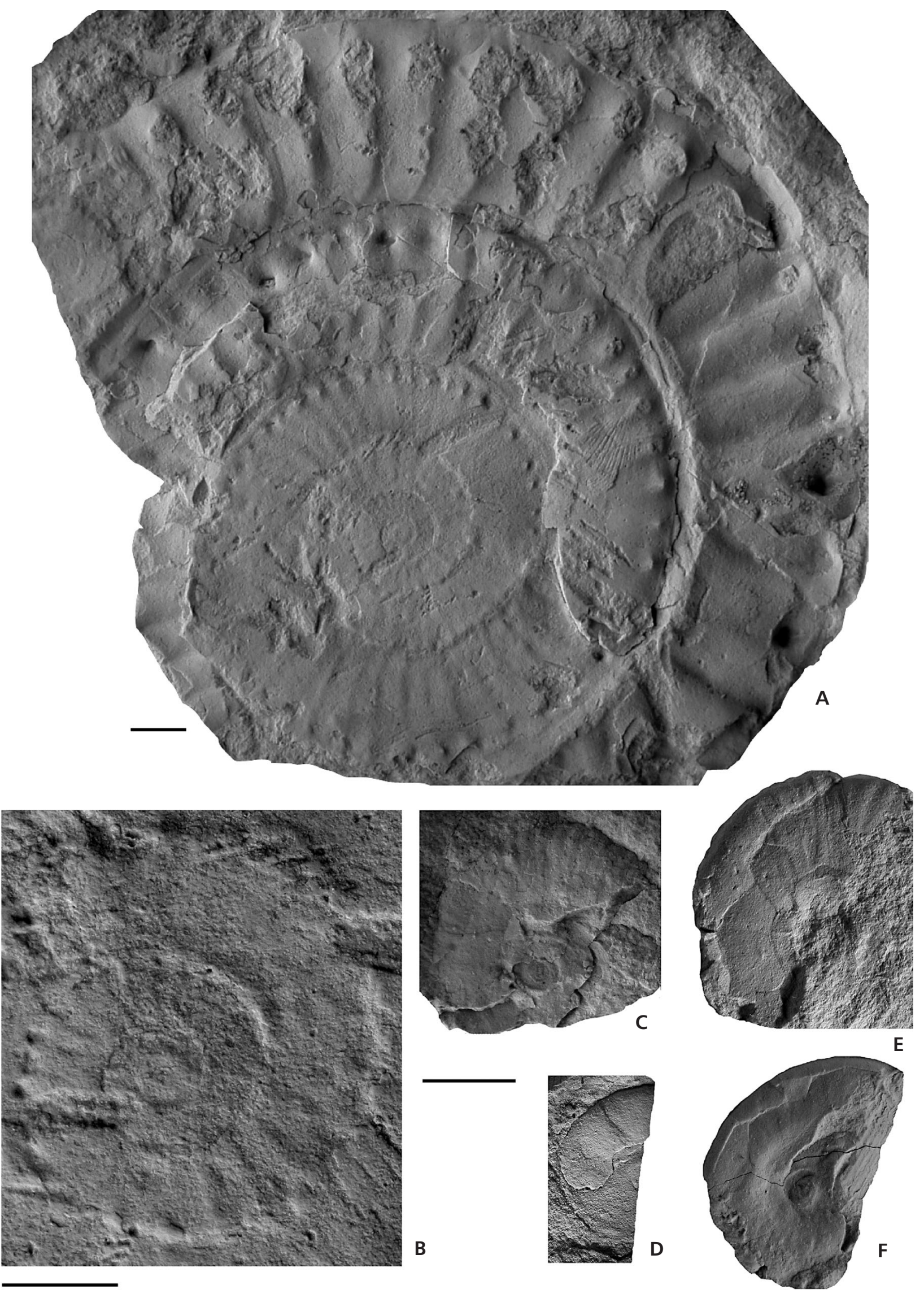



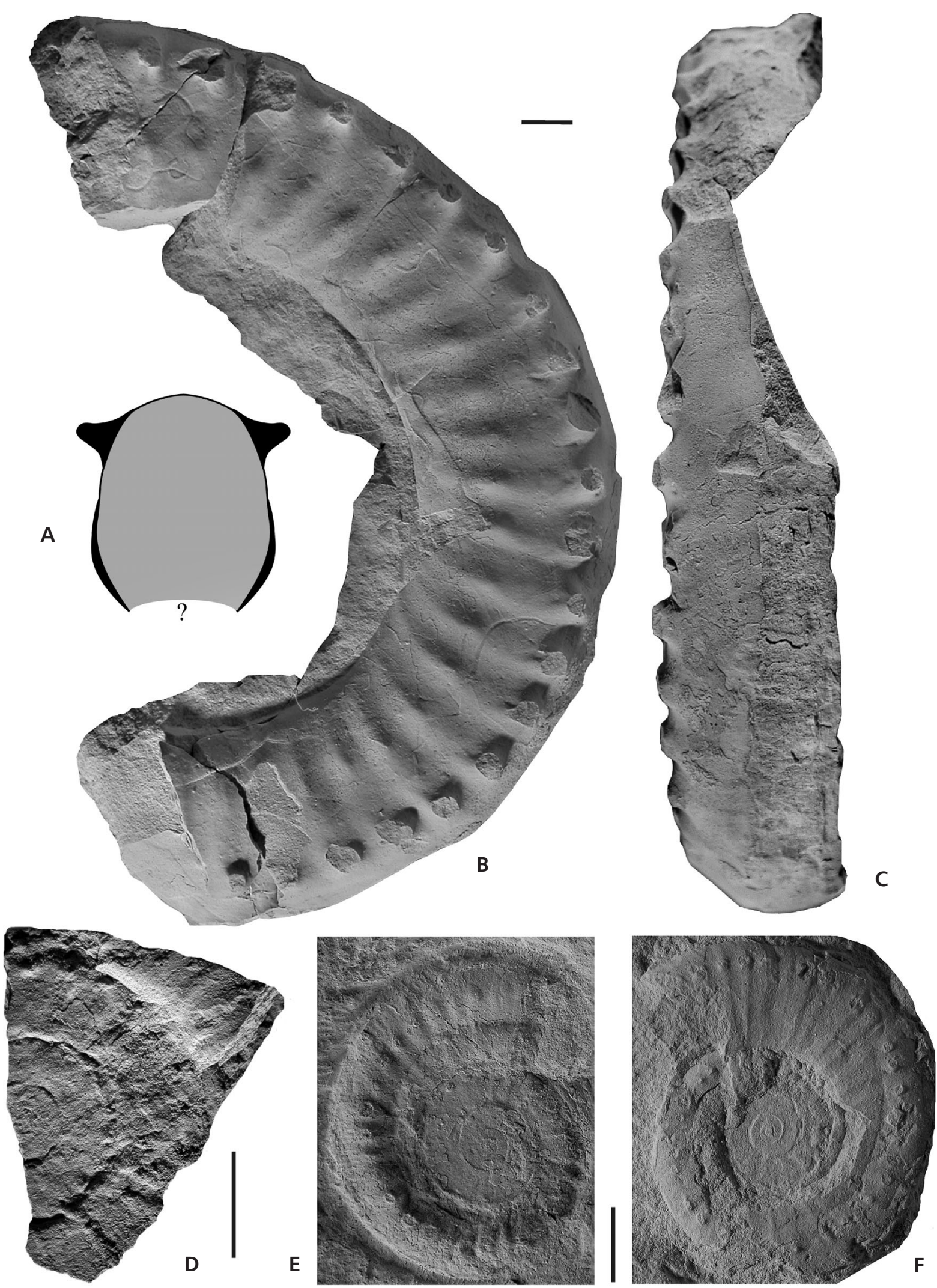

Figure 5. Early Pliensbachian ammonites (A. dunrobinense biohorizon) from Água de Madeiros. - A-C - Apoderoceras dunrobinense Spath, 1926. $\mathrm{A}, \mathrm{B}$ - part of the body chamber with $\mathrm{C}$ the whorl section (diameter $=170 \mathrm{~mm}$ ). $\bullet \mathrm{D}-\mathrm{F}-$ Apoderoceras dunrobinense Spath, 1926 . D - form ' $\mathrm{b}$ ' inner whorls; E, F - forms 'a' inner whorls. Scale bar $=10 \mathrm{~mm}$. 


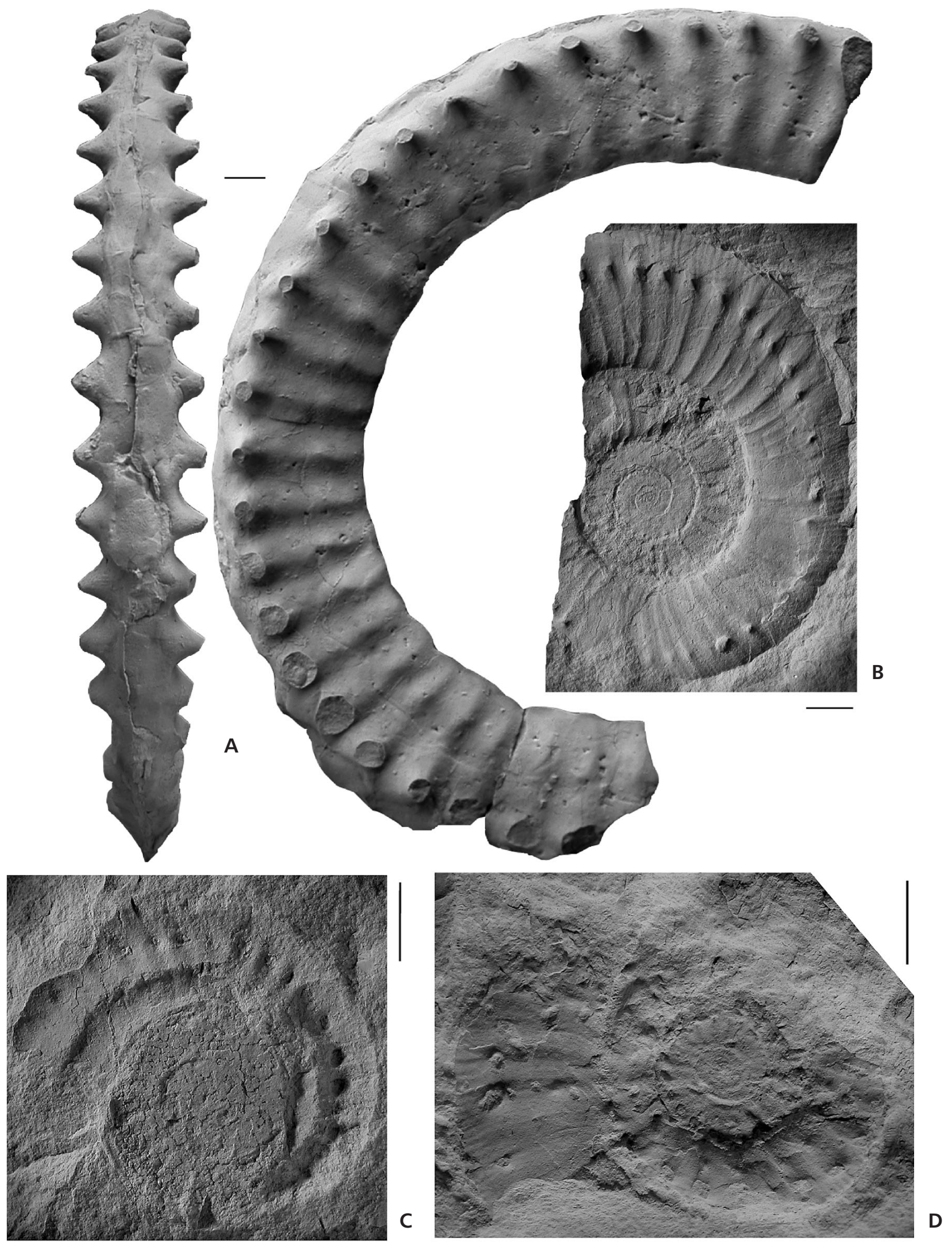

Figure 6. Early Pliensbachian ammonites (A. dunrobinense biohorizon) from Água de Madeiros. • A, B - Apoderoceras dunrobinense Spath, 1926. A - part of the body chamber (diameter $=215 \mathrm{~mm}$ ); B - form ' $a$ ' inner whorls. $\bullet C, D-$ Apoderoceras dunrobinense Spath, 1926. C - form 'a' inner whorls; $\mathrm{D}-$ form 'b' inner whorls. Scale bar $=10 \mathrm{~mm}$. 

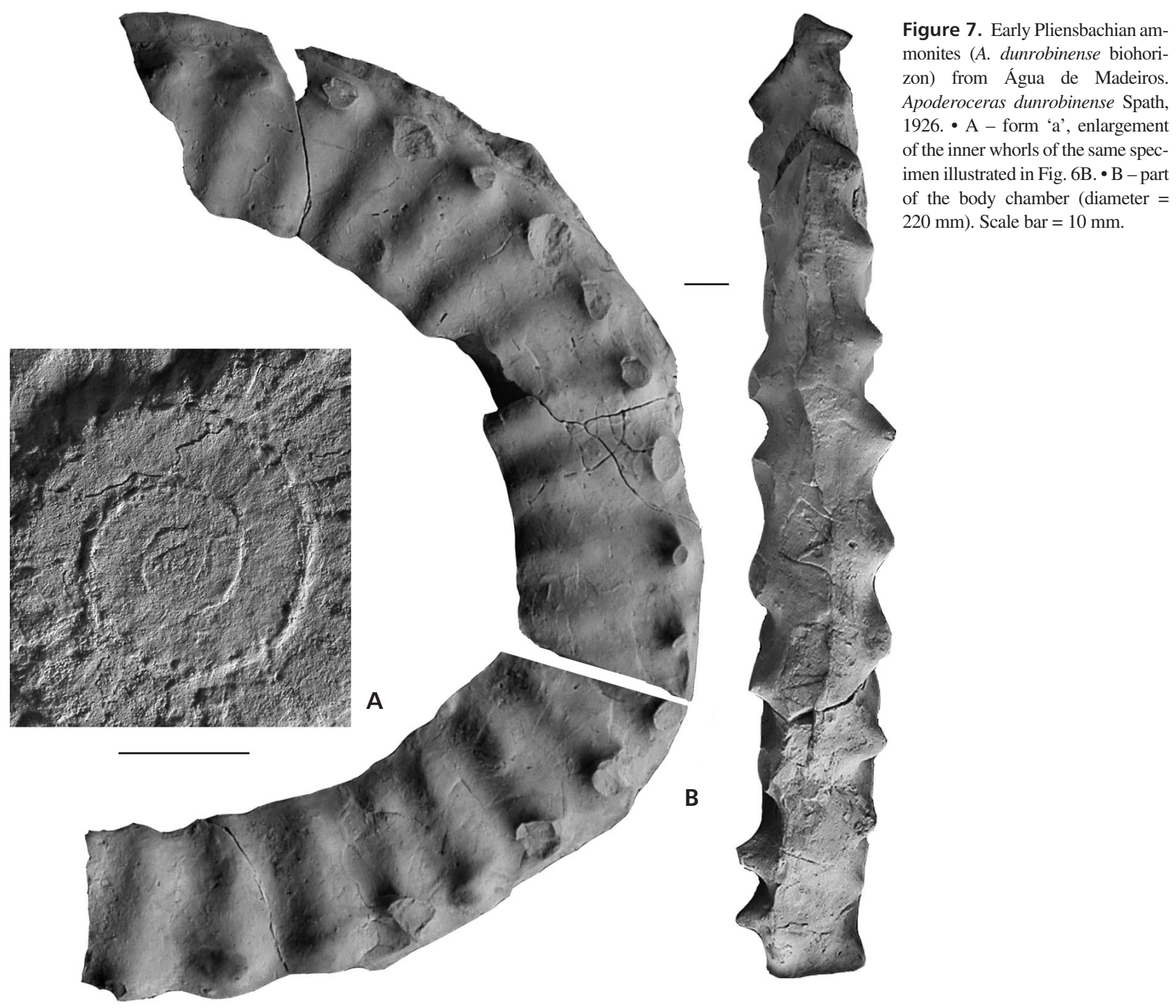

1926 Apoderoceras dunrobinense Spath, p. 47, footnote 1.

?1967a Apoderoceras leckenbyi (Wright). - Mouterde, p. 190.

?1967a Eoderoceras cf. miles (Simpson). - Mouterde, p. 190.

?1967a Eoderoceras aff. armatum (Sowerby). - Mouterde, p. 190.

?1967a Eoderoceras sp. - Mouterde, p. 190.

?1967b Eoderoceras gr. armatum. - Mouterde, p. 212.

?1967b Eoderoceras leckenbyi. - Mouterde, p. 212.

1976 Apoderoceras dunrobinense Spath. - Géczy, pl. 5, fig. 2.

1978 Apoderoceras sp. voisin de A. dunrobiense Spath. Mouterde, Rocha \& Ruget, p. 88.

1978 Apoderoceras sp. - Mouterde, Rocha \& Ruget, p. 88.

1981 Apoderoceras sp. cf. dunrobinense Spath. - Mouterde, Rocha \& Delance, pl. 4, fig. 5.

2003 Apoderoceras cf. dunrobinense Spath. - Edmunds, Varah \& Bentley, pl. 9, fig. 3.
Remarks. - Several taxa cited by Mouterde (1967a, p. 190 and 1967b, p. 212) under the names Apoderoceras leckenbyi (Wright), Eoderoceras cf. miles (Simpson), Eoderoceras aff. armatum (Sowerby) and Eoderoceras sp. are recorded from levels 19e of Água de Madeiros profile. They probably belong to the Apoderoceras dunrobinense Spath, but this fauna is not illustrated and was not found in the Mouterde's collection. A doubt remains concerning their systematic position and is indicated with a question mark in the synonymy list.

In Portugal, the first citation of $A$. dunrobinense Spath is made by Mouterde et al. (1978, p. 88) for the Quiaios profile in Mondego area.

Material. - 24 specimens including 13 large ones with crushed inner and intermediary whorls and 11 small samples showing more or less well preserved inner and intermediate whorls. 
Figure 8. Early Pliensbachian ammonites (A. dunrobinense biohorizon) from Água de Madeiros. Apoderoceras dunrobinense Spath, 1926 (diameter $=253 \mathrm{~mm})$. Scale bar $=10 \mathrm{~mm}$.

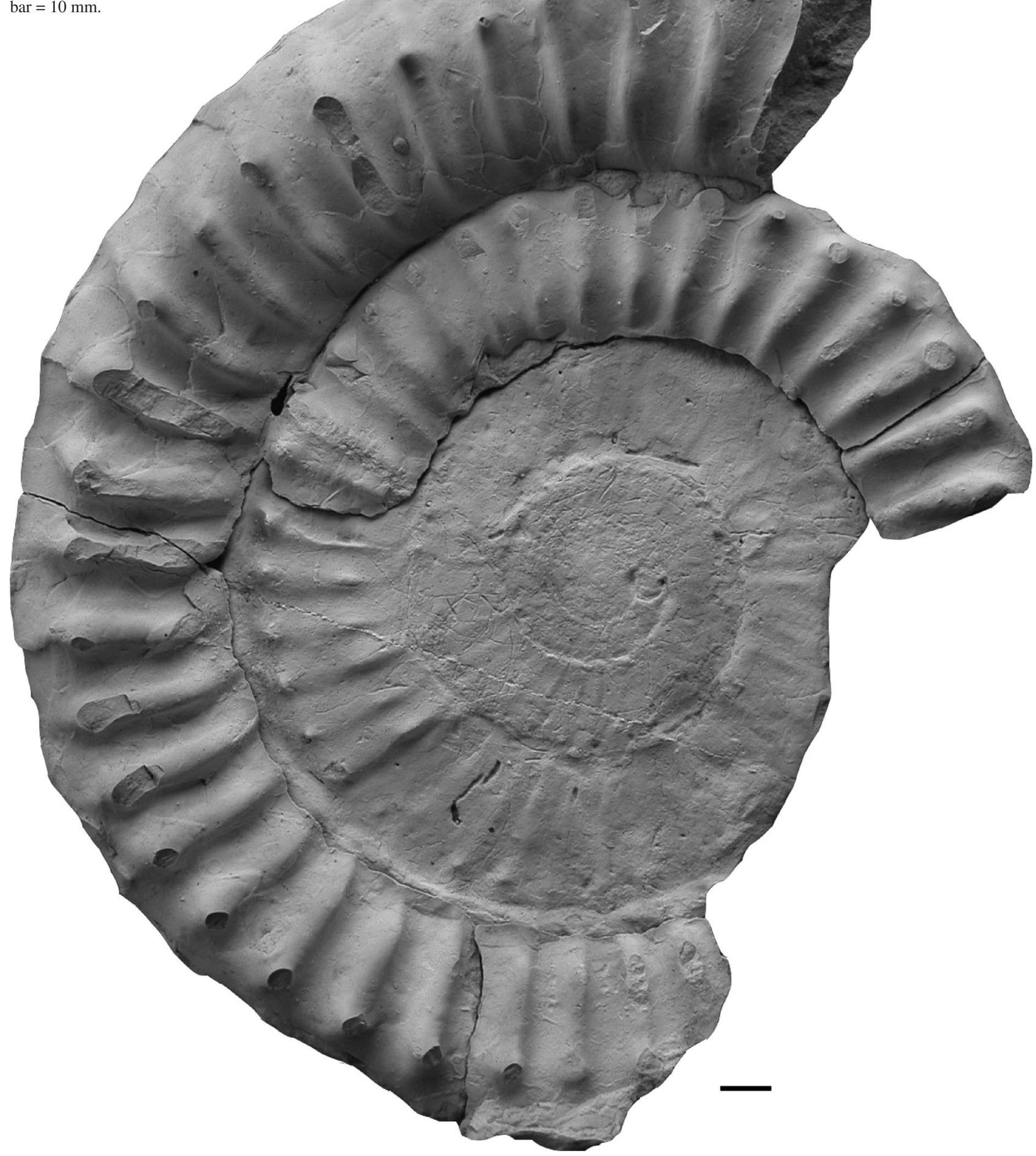

Description. - These forms are characterized by a serpenticone coiling and by their size, the largest exceeds $250 \mathrm{~mm}$ in diameter.

In some specimens the innermost whorls exhibit a finely ribbed stage, almost smooth until $c a 12$ à $18 \mathrm{~mm}$ diameter (e.g. Fig. 6B), while for others, this 'smooth' stage is reduced to $c a 6 \mathrm{~mm}$ diameter (e.g. Fig. 16B). The cadicone habitus of the inner whorls is not very developed, indeed 


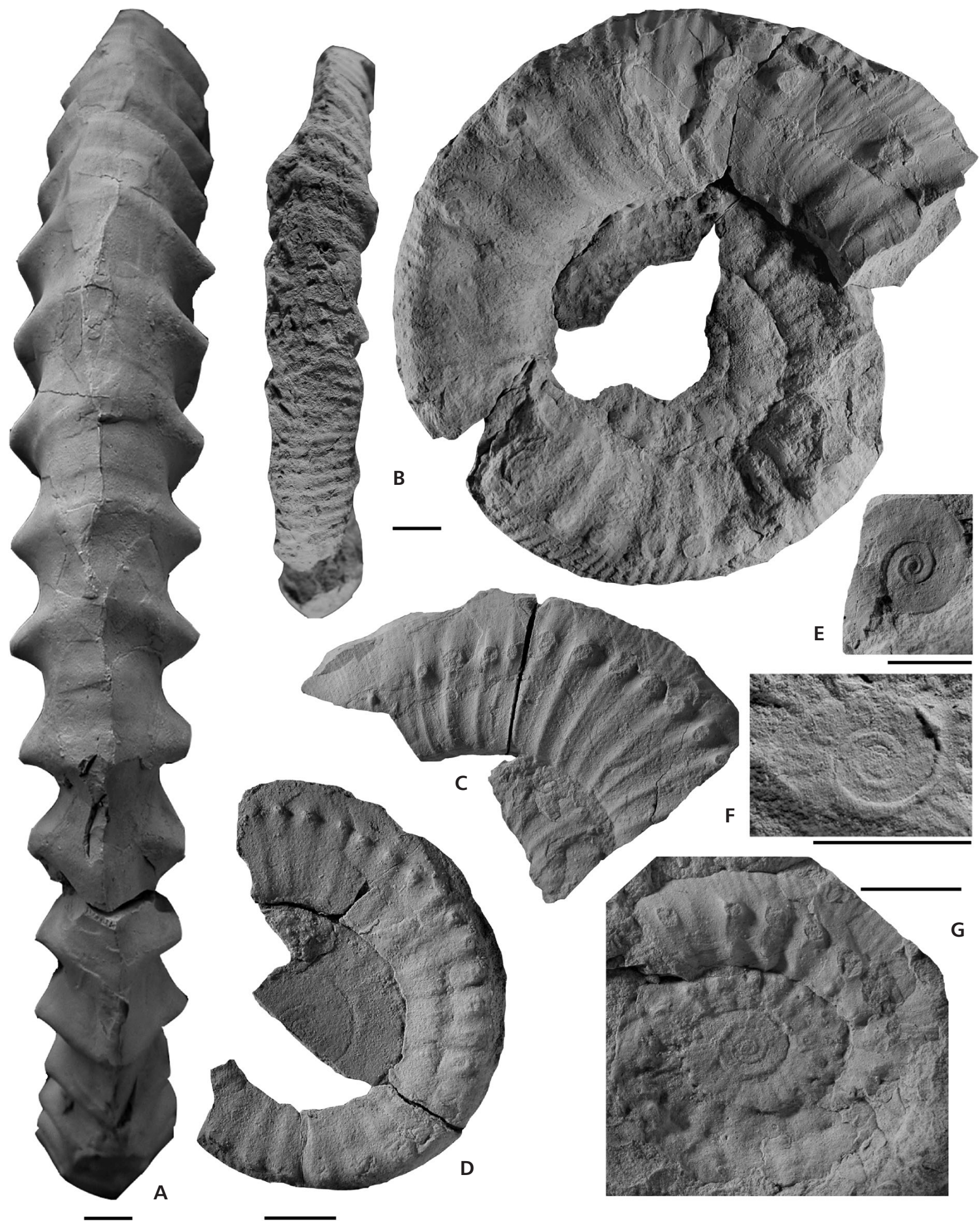

Figure 9. Early Pliensbachian ammonites (A. dunrobinense biohorizon) from Água de Madeiros. Apoderoceras dunrobinense Spath, 1926. A - a part of the body chamber (diameter $=253 \mathrm{~mm}$ ), ventral part of specimen illustrated in Fig. 8. $\bullet$ B, C, D - form 'a' (?). E, F, G - inner whorls, notice the small bullae in specimen $\mathrm{G}$ (bullae are accentuated by the crushing). Scale bar $=10 \mathrm{~mm}$. 


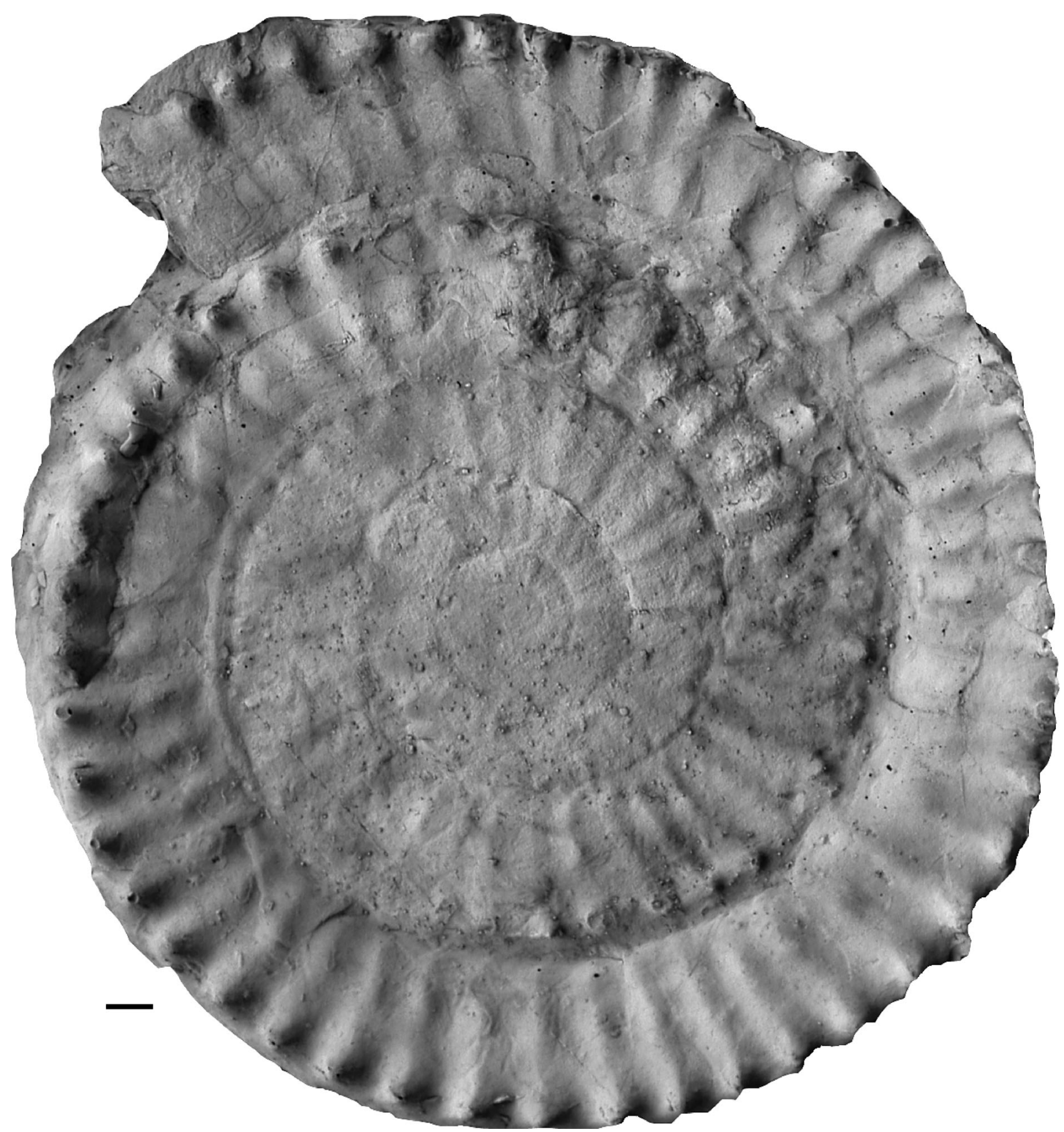

Figure 10. Early Pliensbachian ammonites (A. dunrobinense biohorizon) from Água de Madeiros. Apoderoceras dunrobinense Spath, 1926 (diameter $=238 \mathrm{~mm}$ ). Scale bar $=10 \mathrm{~mm}$.

almost non-existent. This can lead to confusion with the inner whorls of Eoderoceratidae like Eteoderoceras.

Then in all the specimens, a strong ornamentation appears that is composed of ribs, slightly rursiradiate on the umbilical edge, becoming subradiate and strong on the flank and bearing a bullae-like reinforcement on the lower part of the flank, then continuing and thickening on the up- per part of the flank until the spiny tubercles and ending just after them on the ventrolateral part (e.g. Fig. 9B).

For the coarser specimens (e.g. Figs 6D, 9G) the nodosity on the lower part of the flanks is well developed conferring a bituberculation-like habitus. This reinforcement is weakly expressed in some specimens but always obvious in the adult. 
Figure 11. Early Pliensbachian ammonites (A. dunrobinense biohorizon) from Água de Madeiros. Apoderoceras dunrobinense Spath, 1926 (diameter = $270 \mathrm{~mm}$ ), form ' $b$ ' deposited in the Faculty of Science, Caparica (No. AGM 74.01). Scale bar $=10 \mathrm{~mm}$.

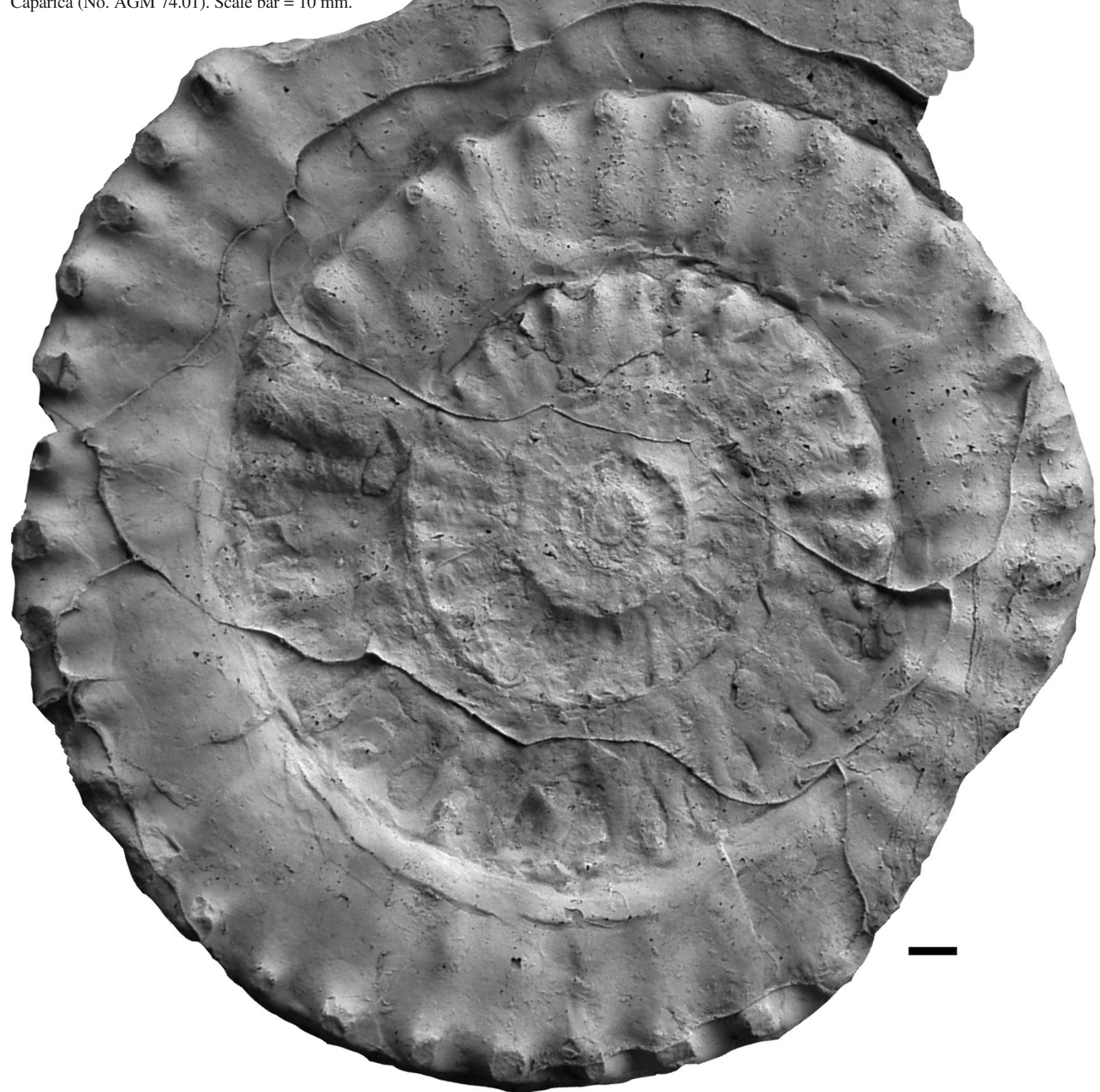

On the rather high convex ventral part, a fine and close secondary ribbing is developed and is obvious at least as far as $100 \mathrm{~mm}$ diameter (inner - intermediate whorls; e.g. Fig. 6B). On some specimens, fine secondary ribs cover the primary ribbing (e.g. Fig. 9B). This character superficially resembles the ornamentation of Apoderoceras aculeatum (Simpson 1855).

In the adults, the ribs remain well developed on the lower part of the flanks and the tubercles become true spines (e.g. Fig. 5B). The monotony of the ornamentation throughout the ontogeny is notable. Only some rare specimens show a tendency for the ribs to fade on the lower part of the flanks, maybe an artefact of preservation. The ventral part becomes smooth (e.g. Fig. 13A).

The thickness of the whorls is preserved in two specimens only, showing a thick subelleptic whorl section 
Figure 12. Early Pliensbachian ammonites (A. dunrobinense biohorizon) from Água de Madeiros. Apoderoceras dunrobinense Spath, 1926 (diameter $=$ $254 \mathrm{~mm}$ ) form 'a'. Scale bar $=10 \mathrm{~mm}$.

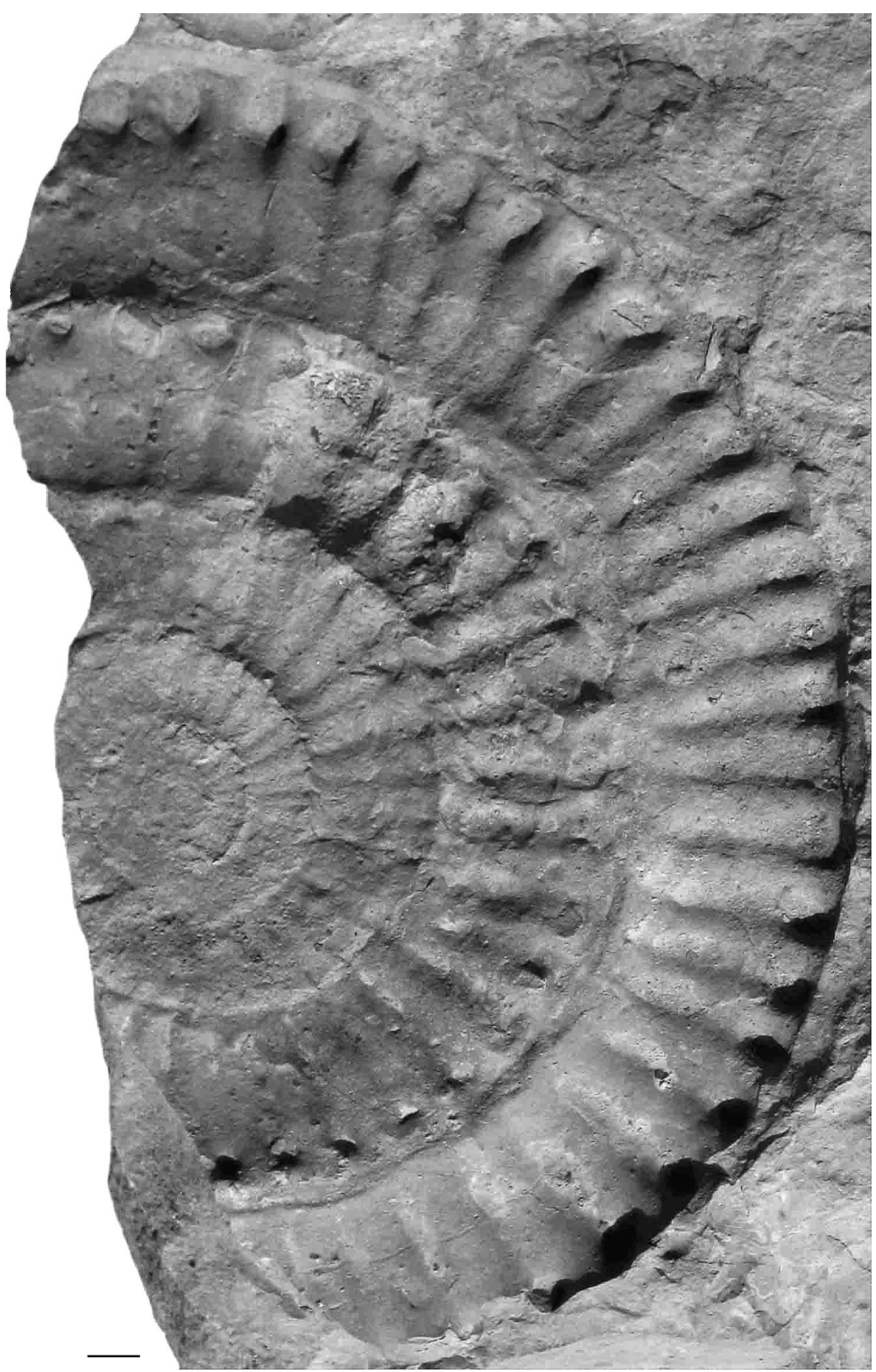

$(\mathrm{Ww} / \mathrm{Wh}=0.78-0.83)$ with slightly convex flanks and flat rounded venter (Figs 5C, 13A). These specimens clearly show a very original character for an Apoderoceras, with the developement of weak regular nodosities on the lower part of the flanks precisely on the $2 / 5$ of the flank, the outer row of spines being situated on the $4 / 5$ of the flank (Figs 5A-C, 13B).

Our population has a weak morphological variability for the ornamentation and for the coiling, even if some specimens (e.g. Figs 10,12) show a more or less coarse and close ornamentation in the adult stage. In fact the variability is only significant in the innermost whorls. So two morphs of A. dunrobinense Spath: form 'a' corresponding to the 'long' smooth stages and form ' $b$ ' corresponding to the 'short' smooth stage associated with a precocious coarse 'bi-' tuberculated development can be distinguished. These two 
kinds of morphologies can be observed in other Apoderoceras. In that way, A. nodogigas (Quenstedt) illustrated by Quenstedt (1882-1885, pl. 27, fig. 9) shows a serpenticone stage, smooth in the very inner whorls. We observe the same habitus in one specimen from the Yorkshire Coast (Meister et al. 2003, pl. 2, fig. 27). A. (?) marshallani (Simpson) also has rather smooth serpenticone innermost whorls. Conversely, in A. aculeatum (Simpson) (Howarth 2002, pl. 6, fig. 2; Hoffmann 1982, pl. 17, fig. 1) or in A. subtriangulare (Young \& Bird) (Howarth 2002, pl. 6, fig. 4a; Edmunds 2009, pl. 28, fig. 3) the ribbing of the very inner whorls and the cadicone habitus are clearly expressed.

An original feature of the population studied is the serpenticone coiling associated with a regular strong ornamentation throughout ontogeny, in particular the persistence of the ribs on the lower part of the flanks and the presence of a row of weak nodosities on the lower part of the flanks. They also have a rather more slender habitus than the other Apoderoceras. This combination of traits defines Apoderoceras dunrobinense Spath.

A. dunrobinense Spath is characterized by well developed ribbing from the umbilicus to the ventrolateral edge throughout the ontogeny. The whorls are quite massive with a slow growth rate $(\mathrm{Ww} / \mathrm{Wh} \sim 1)$. Our specimens are close to the type species illustrated by Quenstedt (1882-1885, pl. 25, fig. 6).

A. cf. dunrobinense Spath in Edmunds et al. (2003, fig. 9.3) perhaps shows a slightly denser ribbing and is situated in the variability of the strong rib density group. The Portugese form illustrated by Mouterde et al. (1981, pl. 4, fig. 5) shows a medium rib density, only the last third of the whorl is more finely and densely ribbed. Notice the presence of nodosities at the lower part of the flank.

In the Portuguese population, the rib density (N/2) very slowly increases during the ontogeny with a slight stagnation phasis (decrease) near 170-180 mm diameter at least for the specimen illustrated in Fig. 10 (Fig. 17). The rib spacing is standardized using the SRS parameter (Standardized Rib Spacing: D / N/2) established by Dommergues \& Bonnot (2007). The clustering of the points shows a weak variability for this character as far as 170-180 mm diameter, then the point scattering becomes wider, probably corresponding to the adult morphology. The SRS varies from about 9-10 $\mathrm{mm}$ to $15-16 \mathrm{~mm}$, showing a relative pre-adult and adult variability in ribbing. For SRS there is no correlation with the ratio N/2 which on the contrary shows a weak increase of the rib density. Notice that the Portuguese form illustrated by Mouterde et al. (1981, pl. 4, fig. 5) from another locality (Vale das Fontes) is well integrated in the variability range of our specimens.

If we compare the Portuguese population with some NW European Apoderoceras characterized with well developed and persistent ribs throughout the ontogeny, we observe the same evolution of N/2 and SRS for the whole Apoderoceras (Fig. 18). There is not much difference, for these two parameters, between the Portuguese fauna and the NW European Apoderoceras. Their evolution remains quite homogeneous. Nevertheless, the points are now more scattered because of a comparison between several species. After 170-180 mm diameter, the point dispersion is wider but the SRS remains between 9-10 mm and 15-16 mm. We must bear in mind that several 'species' of Apoderoceras are very close, and sometimes only known from fragments, and that the number of valid species is probably lower than the number of nominal species.

Comparison. - A. aculeatum (Simpson) includes A. antiquum Lóczy, A. decussum (Simpson) and A. leckenbyi (Wright). In this species, a less serpenticone coiling associated with more massive whorls, mainly in the adult morphology, distinguishes it from the Portugese specimens (see Géczy 1998, pl. 12, figs 1-3; Howarth 2002, pl. 7, fig. 1; Meister et al. 2003, pl. 2, fig. 23). Moreover, in the intermediate whorls, the ribbing is finer, and irregular in intensity and spacing (see Donovan \& Surlyk 2003, p. 575, fig. 4). At a similar diameter our specimens seem to have an attenuated 'aculeatum ornamented stage', but the adult ornamentation remains totaly different in Simpson's species with only the preservation of a spaced spiny row (see Buckman 1913, pl. 72B).

A. dubari Géczy is a form with broad and massive, rather rounded, whorls and with less expressed tubercles. It is close to A. aculeatum (Simpson) but with slower growth in whorl height.

A. ferox Buckman, a very large specimen (500 mm diameter), has a very slow whorl growth rate and marginal tubercles associated with a barely convex ventral part. Its ribbing is spaced and very coarse, hardly developed and fading on the lower part of the flanks. Whorls are clearly broader than high.

A. hamiltoni (Simpson) is a form with a slow growth rate and its size exceeds $400 \mathrm{~mm}$ diameter. The whorls are close to those of A. aculeatum (Simpson) but the rib density is very low at comparable diameters $(\mathrm{N} / 2=13$ for a diameter of $290 \mathrm{~mm}$ ). It superficially resembles the Portuguese specimens.

Figure 13. Early Pliensbachian ammonites (A. dunrobinense biohorizon) from Água de Madeiros. $・ \mathrm{~A}, \mathrm{~B}, \mathrm{C}, \mathrm{D}, \mathrm{E}-$ Apoderoceras dunrobinense Spath, 1926. A, B - part of the body chamber with C the whorl section. D - form ' $b$ ' (diameter $=184 \mathrm{~mm})$. E-complete ventro-lateral spine. Scale bar $=10 \mathrm{~mm}$. 
Christian Meister et al. • Ammonites from the Apoderoceras beds, Pliensbachian, Lusitanian Basin

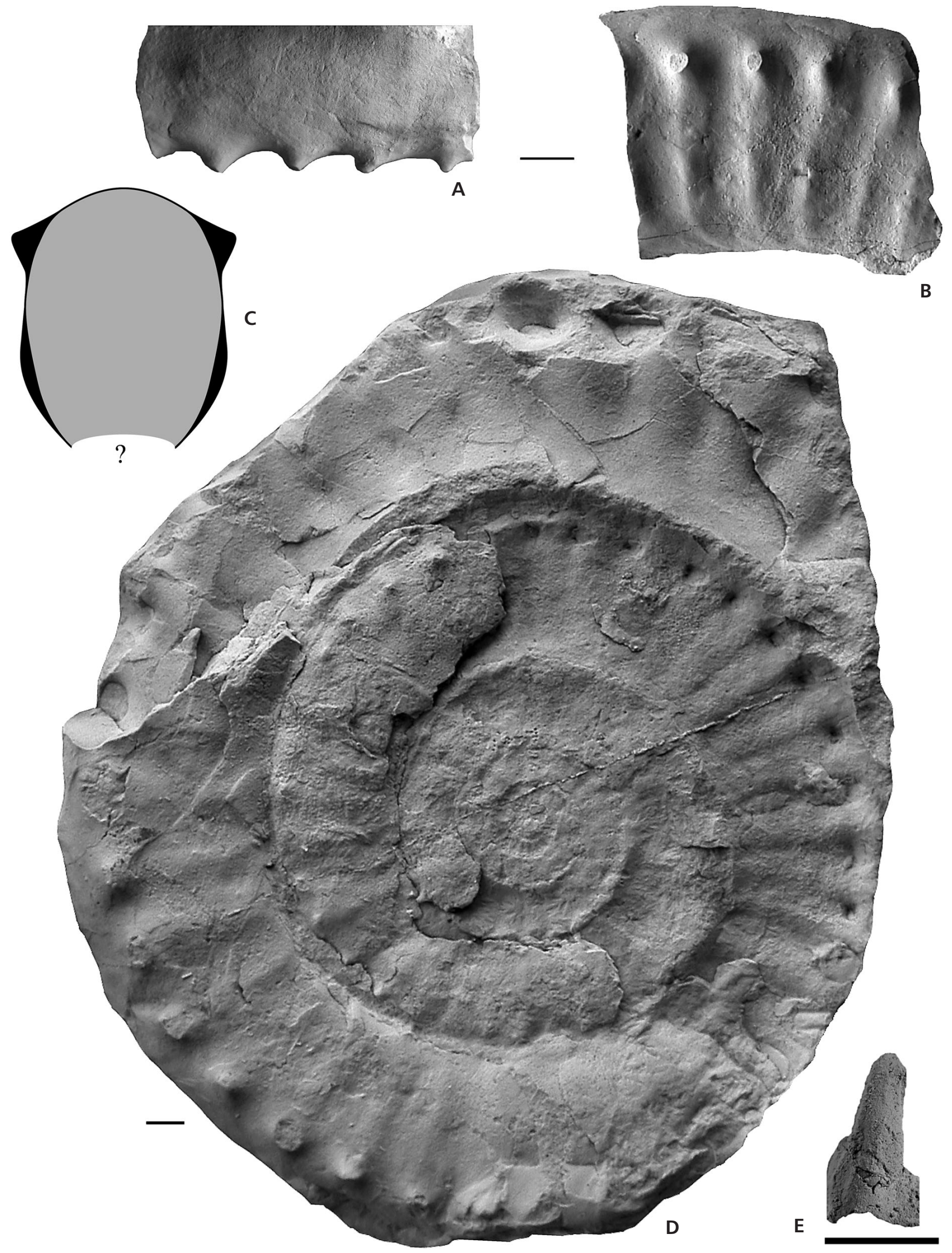




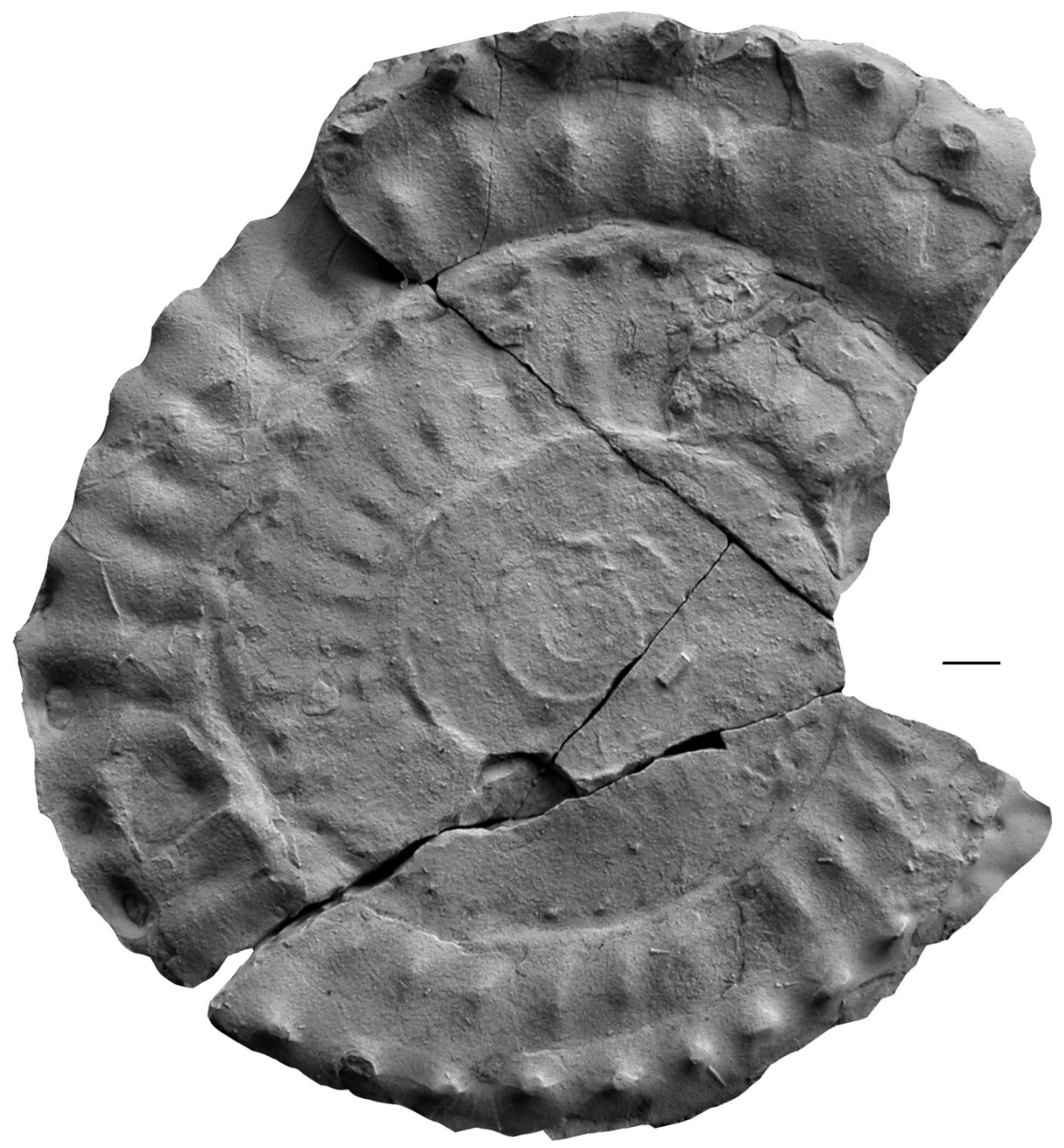

Figure 14. Early Pliensbachian ammonites (A. dunrobinense biohorizon) from Água de Madeiros. Apoderoceras dunrobinense Spath, $1926($ diameter $=200 \mathrm{~mm})$. Scale bar $=10 \mathrm{~mm}$.
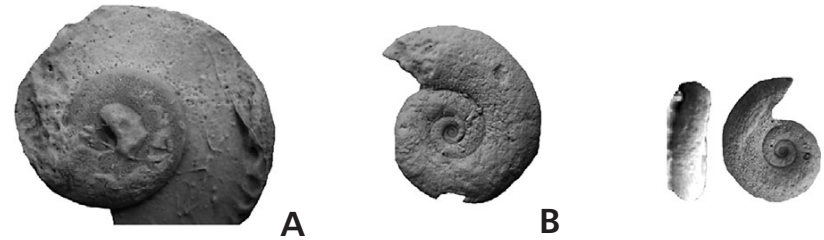

C
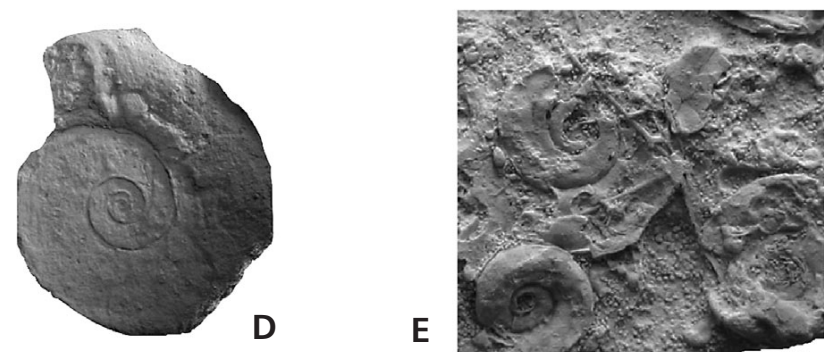

Figure 15. Early Pliensbachian gasteropods (A. dunrobinense biohorizon) from Água de Madeiros. - A-E - small undetermined gasteropods (= Gemmellaroceras sp. sensu Antunes et al., 1981). Scale bar $=10 \mathrm{~mm}$.
'A' limatum Pompeckj is close to A. lobulatum Buckman with rounded whorls; both lack ornament at a small diameter $(\mathrm{D}=100 \mathrm{~mm})$. Moreover A. lobulatum Buckman is a massive form with rounded, broader than high, whorls.

A. nodogigas (Quenstedt) with its smooth inner whorls followed by a well expressed ribbed stage shows a quite high rib density. The ribbing seems to persist during the whole ontogeny. Tuberculation is present but little developed in the inner and middle whorls, becoming spiny in the outer whorls. This ornament habitus also closely related to the Portuguese forms.

A. sparsinodosum (Quenstedt) shows a convex ventral area, a very coarse ornament with blunt, thickened ribs on the upper part of the flanks and very thick, strong tubercles. Whorls are very massive and broader than they are high.

A. spicatum (Simpson) has a slow growth and bears strong spines and poorly developed ribs on the lower part of the flanks in the adult. This species is only known from fragments of large specimens. 


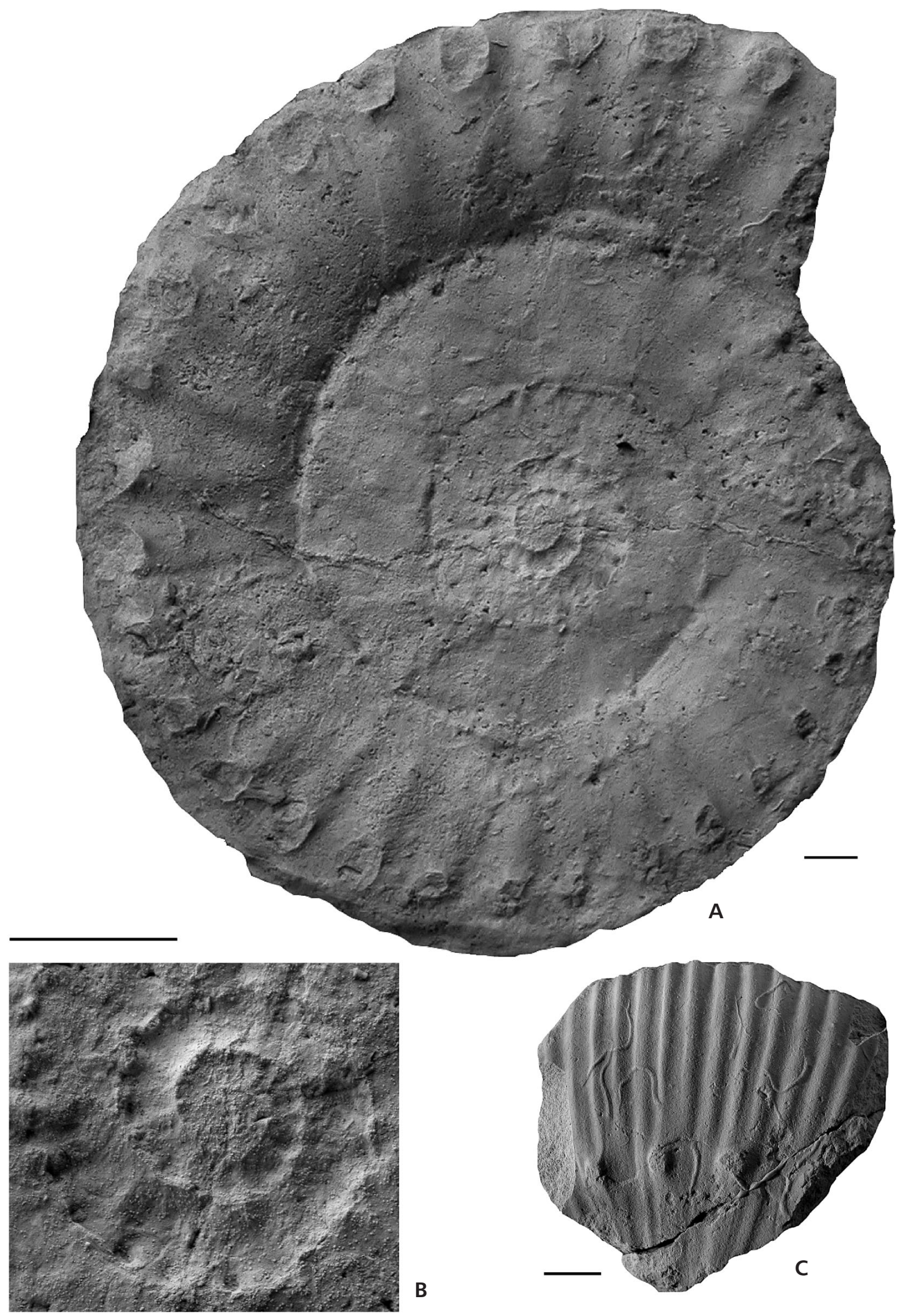

Figure 16. Early Pliensbachian ammonites (A. dunrobinense biohorizon) from Água de Madeiros. • A, B - Apoderoceras dunrobinense Spath, 1926. $\mathrm{A}-$ form ' $\mathrm{b}$ ' (diameter $=178 \mathrm{~mm}$ ); B - enlargement of the inner whorls of A. $\bullet \mathrm{C}-$ Vicininodiceras aff. mouterdei Donovan, 1990. Scale bar $=10 \mathrm{~mm}$. 


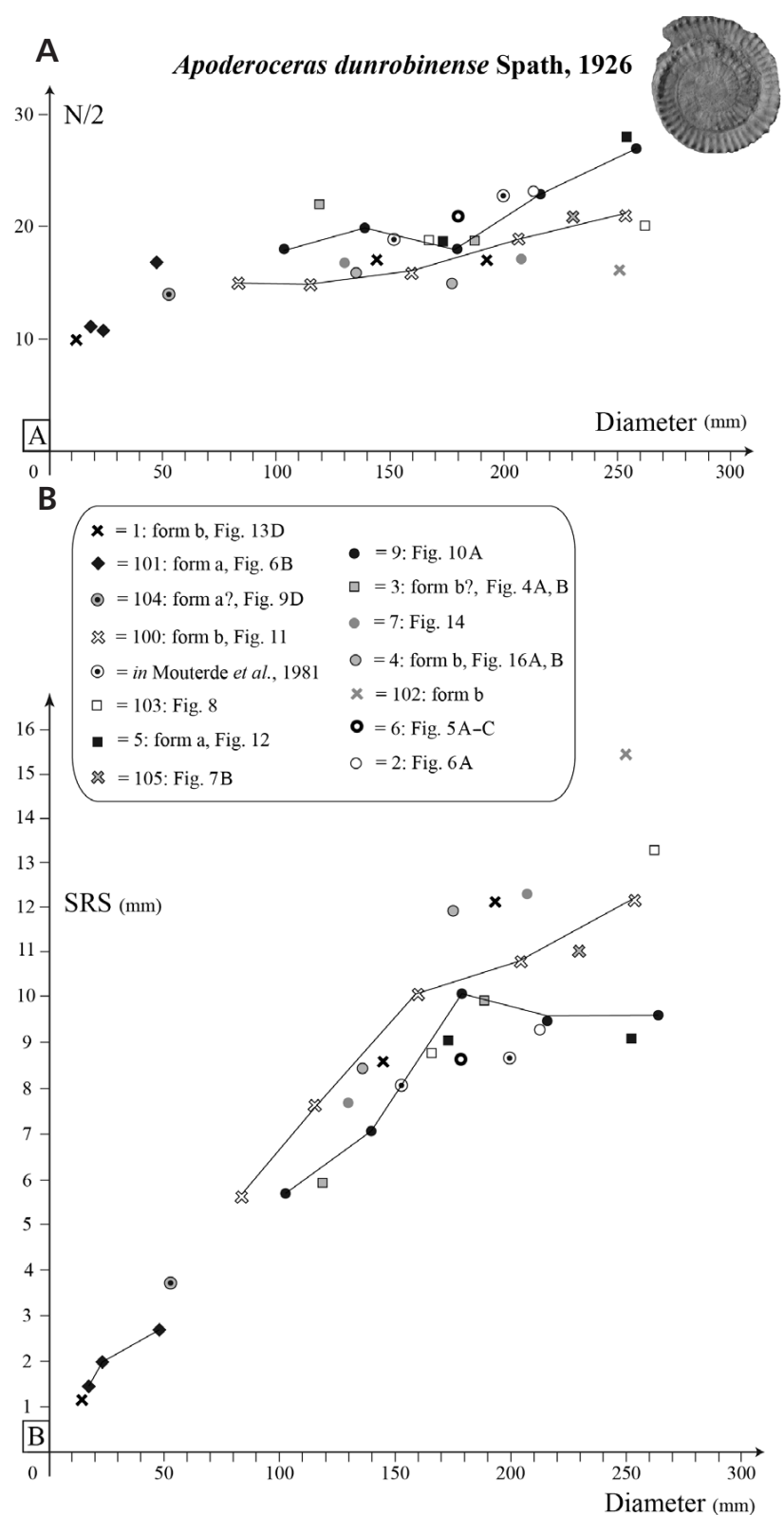

Figure 17. A - illustration of the ontogenetic variations of the rib number per half whorl (N/2) versus the diameter (D) for the Portuguese Apoderoceras dunrobinense Spath. - B - variations of their inter-rib spacement (SRS) per half whorl versus diameter for the same specimens.

A. subtriangulare (Young \& Bird) is described from one small fragment. This has a subtrapezoidal whorl section, clearly broader than high. The forms illustrated by Howarth (2002, pl. 6, figs 4a, 5a) show cadicone stages in their inner whorls.

The A. subtriangulare (Young \& Bird) sensu Edmunds et al. (2003, fig. 9.1, 2; fig. 11.1, 2) contains massive whorl forms some of which are serpenticone similar to the type (ibid., fig. 9.1,2) with a more finely ornamented stage $(\mathrm{N} / 2=20)$ becoming coarser but still closely ornamented
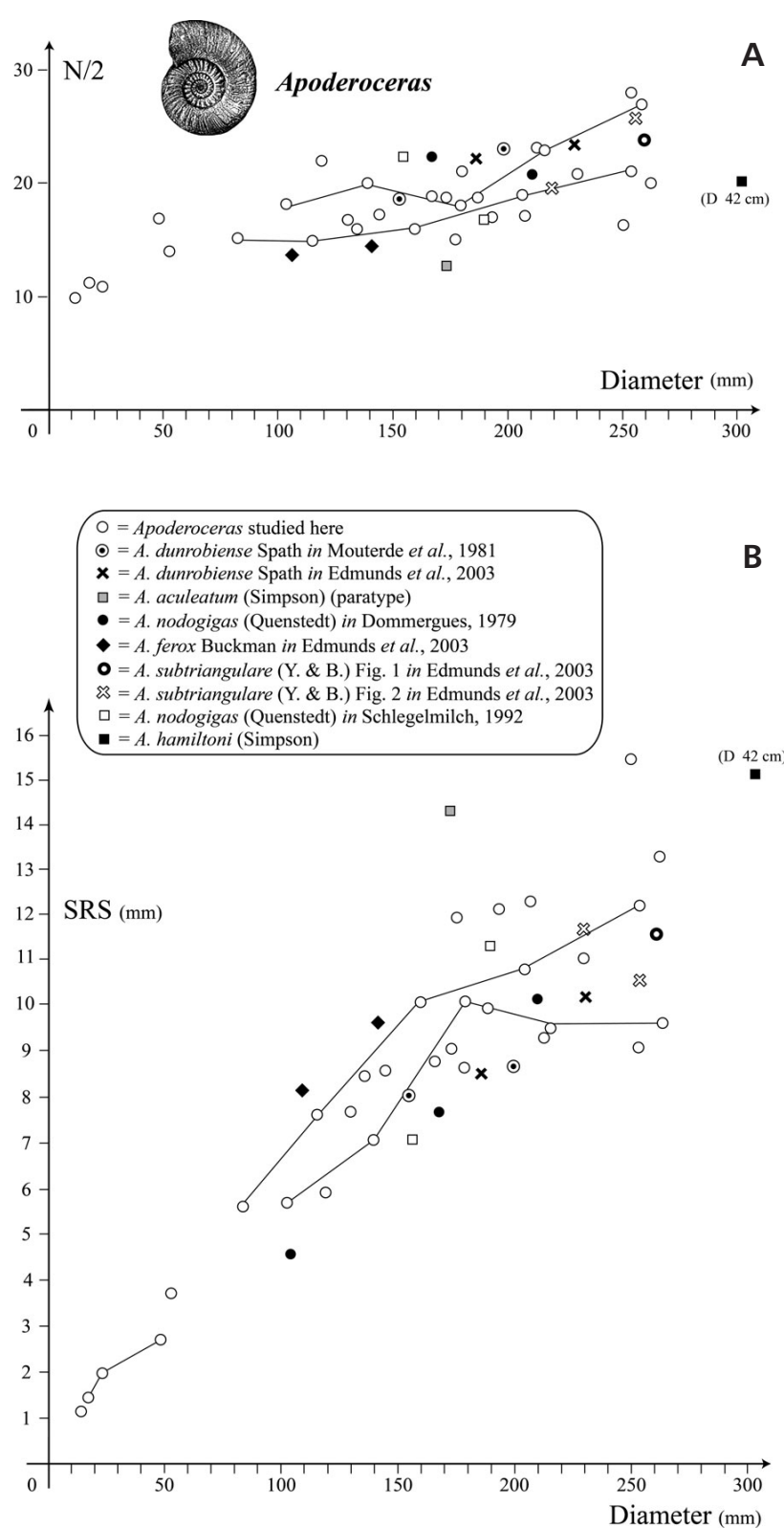

Figure 18. A - illustration of the ontogenetic variations of the rib number per half whorl (N/2) versus the diameter (D) for different species of Apoderoceras. $\bullet \mathrm{B}$ - variations of their inter-rib spacement (SRS) per half whorl versus diameter for the same specimens.

in the adult $(\mathrm{N} / 2=25)$. At the same time these authors include forms with more rapid coiling, clearly different from true A. subtriangulare (Young \& Bird) (ibid., fig. 11.1,2) suggesting a large variability.

A. tardarmatum Buckman belongs to the large forms with massive whorls like A. subtriangulare (Young \& Bird) or A. sparsinodosum (Quenstedt). Its ventral part is broad and convex.

A. triornatum Buckman shows a strong irregularity of the ornament in the inner whorls where the secondary 


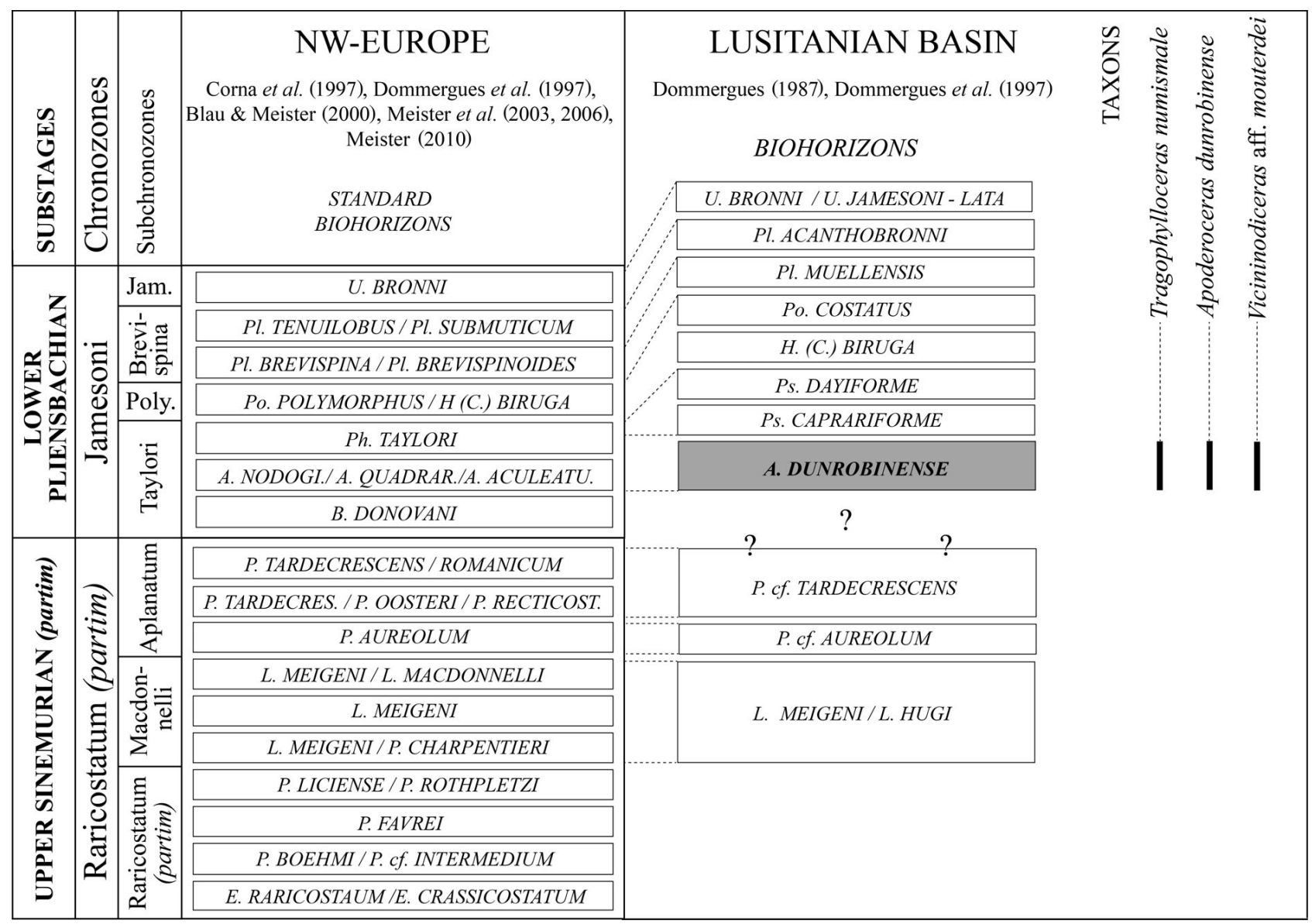

Figure 19. Biohorizon succession near the Sinemurian-Pliensbachian boundary for NW Europe and Lusitanian Basin with the position of the new A. dunrobinense biohorizon and its associate fauna.

ribbing obliterates the primary tuberculate ribs as for some Apoderoceras [A. aculeatum (Simpson), A. subtriangulare (Young \& Bird) or A. tardarmatum Buckman]. Its whorl section is higher than it is broad, quite close to the one of the Portuguese specimens (Figs 5A, $13 \mathrm{C}$ ); nevertheless the whorl growth is faster (less serpenticone whorls).

Two doubful Apoderoceras [(?) A. sinuatum (Simpson) illustrated by Buckman (1914, pl. 94) and (?) A. armiger (Simpson) according to Simpson's description (1855, p. 66)] do not show close morphological affinities with the Portuguese specimens.

The serpenticone coiling and the persistance of the ribbing with a tendency towards a 'bituberculate' habitus of A. dunrobinense Spath superficially also resemble some bituberculate Eoderoceratidae like Microderoceras s.l. or Bakonyceras, which are, among others, clearly bituberculate.

Age and distribution. - The stratigraphic repartition of the different species of Apoderoceras in the Jamesoni Chronozone remains poorly known. Nevertheless, the first Apoderoceras are pratically present at the base of the Pliensbachian, like A. aculeatum (Simpson) in the stratotype of the Pliensbachian in Wine Haven (Yorshire, UK) (see Dommergues \& Meister 1992; Meister et al. 2003, 2006).

A. dunrobinense Spath is recorded from SW Germany, ?Hungary (Upper Austroalpine unit), UK (Somerset) and Portugal. The new data from Portugal, with the association of $T$. numismale (Quenstedt), Spath's species and $V$. aff. mouterdei Donovan, allow us to situate it in the lower part of the Jamesoni Chronozone (lower to middle Taylori Subchronozone), which is correlated with the Apoderoceras ssp. and partim with the $P$. taylori standard biohorizons (Fig. 19).

Remarks. - São Pedro de Muel is situated in a rather basinal position where the ammonite succession is clear with an Upper Sinemurian ammonite fauna (with true Eteoderoceras) that is located far below the Apoderoceras beds. Conversly in Mondego (Quiaios) the stratigraphical context still remains unclear. This area is situated closier to the border of the basin and the ammonite association given by 
Mouterde et al. (1978) suggest a condensed serie with Apoderoceras, Tragophylloceras of Pliensbachian age and with Sinenurian ones like Eteoderoceras. This fauna must be examined again.

Family Liparoceratidae Hyatt, 1867

emend. Dommergues \& Meister, 1999

\section{Genus Vicininodiceras Trueman, 1919}

Type species. - Vicininodiceras simplicicosta Trueman, 1919.

\section{Vicininodiceras aff. mouterdei Donovan, 1990} Figure 16C

1970 Liparoceras (Vicininodiceras?) sp. - Mouterde, pl. 6, fig. 2.

1990 Vicininodiceras mouterdei. - Donovan, p. 33.

?1990 Liparoceras (Vicininodiceras) sp. - Dommergues \& Meister, pl. 2, fig. 5.

Discussion. - A fragment of a Liparoceratidae was found in association with the Apoderoceras. Such ammonites, which also comes from São Pedro de Muel, were illustrated by Mouterde (1970, pl. 6, fig. 2). It is characterized by a subsphaerocone habitus and a liparoceratomorph-like ormanentation. Because of the preservation, only the upper row of lateral tubercles is observable. Almost every tubercle gives rise to two secondary ribs intercalated with a primary one, so increasing the rib density on the ventral part. The ventro-lateral and ventral ribs are thick, subradiate and regular. Lower on the flanks, primary ribs are more irregular in intensity and spacing.

On the basis of these observations, and because of a similar stratigraphical position, we place our specimen near the Vicininodiceras illustrated by Mouterde and reinterpretated by Donovan (1990) as V. mouterdei.

Our specimen also resembles other Liparoceratidae like the Becheiceras. However, this genus differs from Vicininodiceras in having a larger distance between the two rows of tubercles. Becheiceras is a younger genus first known from the Ibex Chrozozone.

The Portuguese forms (also including a Vicininodiceras illustrated by Dommergues \& Meister 1990, pl. 2, fig. 5) show an intermediate morphology between $V$. simplicicosta Trueman (with a more open umbilicus) and the first Becheiceras (smaller umbilicus). Becheiceras proba- bly originated in the Vicininodiceras during the Lower Pliensbachian (top of Jamesoni Chronozone - base Ibex Chronozone) even if some old and recent hypotheses propose origins in the Parinodiceras (a Polymorphitidae) (see Spath 1938, Edmunds 2009).

$V$. gollingense (Rosenberg) has finer ornamentation, while $V$. tomfryi Donovan exhibits a coarser ornamentation, mainly on the flanks.

Age and distribution. - The range of Vicininodiceras is rather restricted and covers a part of the Raricostatum and Jamesoni Chronozones. Most of the Vicininodiceras in the literature are of Upper Sinemurian age (Raricostatum Chronozone) and some more precise indications give a Tardecrescens Subchronozone age. The Portuguese specimens allow us to confirm the Pliensbachian age of this genus. The form mentioned by Mouterde (1970, p. 56) is situated $5 \mathrm{~m}$ above the 'Deroceras' (= Apoderoceras) beds [niv. 20a in Antunes et al. $1981=$ above bed 74 of the present work] and consequently is a little younger than our specimen. However these two Vicininodiceras are of Lower Pliensbachian age (Jamesoni Chronozone).

The genus Vicininodiceras also present in the Upper Sinemurian, it is distributed in the both NW European domain (UK, Luxembourg, Portugal) and the Tethyan domain [Middle Austroalpine of the Italian Rhetic Alps, Upper Austroalpine of Austria and Hungary, Pontides (Turkey), Apennines and Algeria (Grande Kabylie)]. V. aff. mouterdei Donovan is known only from the Lusitanian Basin and doubtfully from the Alps (Fig. 20).

Remarks. - Antunes et al. (1981) cited several Gemmellaroceras $\mathrm{sp}$. (never illustrated) from the 'laminite bed' (unit A in Fig. 3); this information is restated in the most recent literature where authors state that these beds are of decimetre to centimetre thick microspar limestone (rich in ostracods and radiolarians) with planar laminations, Rhizocorallium, Thalassinoides and Gemmellaroceras (e.g. Duarte \& Soares 2002; Duarte et al. 2010, p. 327). Having carefully collected macrofossils in these beds we have found only small gastropods (Fig. 15). These gastropods are very similar in form to Gemmellaroceras and can be confused with this ammonite, but they are not strictly planispirale and no suture line is obvious.

This observation in the 'laminite bed' does not exclude the presence of Gemmellaroceras-like micromorphs in Portugal as attested by the presence of Leptonotoceras leptonotum Spath in Quiaios profile (Mondego area) (Mouterde \& Rocha 1981).

Figure 20. A - paleogeographical reconstruction for the Upper Sinemurian-Lower Pliensbachian period of the Western Tethys and adjacent areas with distribution of T. numismale (Quenstedt), Vicininodiceras and A. dunrobinense Spath. • B - pre-drift sketch maps of the "Iberia-Newfoundland" conju- 


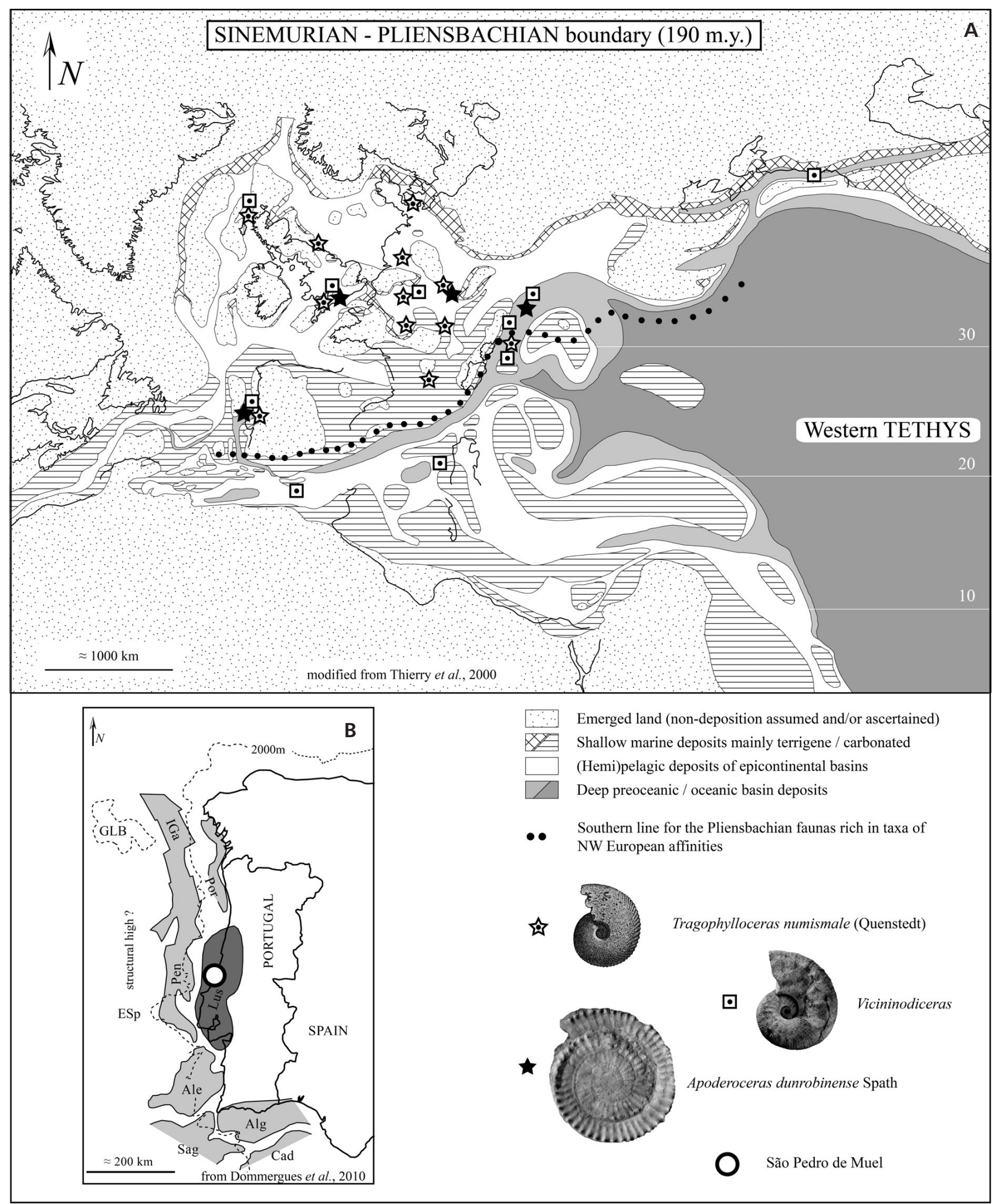

gate margins with location of the main basin. The Iberian landmass is outlined in its present-day configuration as a landmark. The location and extent of Mesozoic pre-drift basins (shaded regions) are approximate only [modified from Srivastava \& Verfoef (1992) and Sandness \& Pacheco (2002)]. The $2000 \mathrm{~m}$ isobath is suggested by dotted lines to approximate the offshore outlines of the Newfoundland and Iberian landmasses. Plate boundaries cannot be pinpointed. Abbreviations: GLB - Galicia Bank; Esp - Estremadura spur; Iga - Inner Galicia Basin; Por - Porto Basin; Pen - Peniche Basin; Lus - Lusitanian Basin; Ale - Alentejo Basin; Alg - Algarve Basin; Sag - Sagres Basin; Cad - Cadiz Basin. 


\section{Concluding remarks}

(i) The Portuguese population of A. dunrobinense Spath is rather homogeneous. These ammonites are characterized by serpenticone coiling associated with a regular strong ornamentation throughout the ontogeny and in the presence of a row of weak nodosities on the lower part of the flanks.

(ii) The A. dunrobinense biohorizon, including beds 50 to 74 , is characterized by the association of the index species with $T$. numismale (Quenstedt) and $V$. aff. mouterdei Donovan and is easily correlated with the standard biohorizons of NW Europe. It corresponds to the lower part of the Jamesoni Chronozone (lower to middle Taylori Subchronozone). This unit can also be precisely correlated with other regions like Yorkshire, Dorset and New Hebrides (UK), NW and SW Germany and Burgundy, Causses, Alps and Pyrénées (France), where equivalent faunas are recorded [e.g. Apoderoceras ssp., Tetraspidoceras quadrarmatum (Dumortier)]. Correlations with Tethyan regions are less precise because of the difference in the composition of the faunas (see Meister 2010). For example, some Microderoceras (Eoderoceras) of North Africa or Catriceras from Hungary of Lowermost Pliensbachian age could be equivalent in age with our faunas.

(iii) In the section of Água de Madeiros, the Sinemurian-Pliensbachian boundary cannot be precisely determined by ammonites (the primary marker to define this boundary) due to the presence of about 10 meters of laminite deposits without ammonites between the Sinemurian Echioceratidae beds and the Pliensbachian Apoderoceras beds.

(iv) T. numismale (Quenstedt) and A. dunrobinense Spath have a paleogeographical distribution restricted mainly to the Euroboreal domain, maybe including the northern margin of the Tethys for Spath's species. This underlines the close connections of the Lusitanian Basin and the Euroboreal seas during the earliest Pliensbachian. The rare genus Vicininodiceras has a rather more ubiquitous paleogeographical distribution, being present in the Euroboreal domain as well as in the Mediterranean Tethys domain.

\section{Acknowledgements}

We thank very much John Hollier from the Natural History Museum of Geneva for the English improvement and both reviewers for their acute comments and suggestions.

\section{References}

Antunes, M.T., Rocha, R.B. \& Wenz, S. 1981. Faunule ichthyologique du Lias inférieur de S. Pedro de Muel, Portugal. Ciências da Terra 6, 101-116.
Arkell, W.J. 1950. A classification of the Jurassic ammonites. Journal of Paleontology 24(3), 354-364.

Arkell, W.J., Kummel, B. \& Wright, C.W. 1957. Mesozoic Ammonoidea, 80-465. In Moore, R.C. (ed.) Treatise on Invertebrate Paleontology, Part L, Mollusca 4; Cephalopoda, Ammonoidea. Geological Society of America \& The University of Kansas Press, Boulder \& Lawrence.

Blau, J. \& Meister, C. 2000. Upper Sinemurian ammonite successions based on 41 faunal horizons: an attempt at worldwide correlations. GeoResearch Forum 6, 3-12.

Buckman, S.S. 1909-1930. Yorkshire Type Ammonites (volumes 1-2), Type Ammonites (volumes 3-7). Wheldon \& Wesley, London.

Choffat, P. 1880. Étude stratigraphique et paléontologique des terrains jurassiques du Portugal. Première livraison - Le Lias et le Dogger au Nord du Tage. Memórias da Secção dos Trabalhos Geológicos de Portugal 12, 1-72.

Choffat, P. 1885. Nouvelles données sur les vallées tiphoniques et sur les éruptions d'ophites et de teschénites en Portugal. Communicações da Commissão do Serviço Geológico de Portugal 1, 113-122.

Choffat, P. 1903-1904. L'Infralias et le Sinémurien du Portugal. Communicações da Commissão do Serviço Geológico de Portugal 5, 49-114.

Cope, J. 1991. Ammonite faunas of the ammonitico rosso of the Pontide mountains, northern Anatolia. Geologica Romana 27, 303-325.

Corna, M., Dommergues, J.-L., Meister, C. \& Mouterde, R. 1997. Sinémurien. Groupe français d'étude du Jurassique: Biostratigraphie du Jurassique ouest-européen et méditerranéen: zonations parallèles et distribution des invertébrés et microfossiles, 9-14. In Cariou, E. \& HantzPergue, P. (eds) Bulletin des Centres de Recherche Exploration-Production Elf-Aquitaine, Mémoire 17.

CUVIER, G. 1798. Tableau élémentaire de l'histoire naturelle des animaux. 710 pp. Baudouin, Paris.

Dommergues, J.-L. 1979. Le Carixien bourguignon. Biostratigraphie, Paléogéographie, Approches paléontologiques et sédimentologiques. $195 \mathrm{pp}$. Thèse de doctorat de 3ème cycle, Université de Dijon, France (inédit).

Dommergues, J.-L. 1987. L'évolution chez les Ammonitina du Lias moyen (Carixien, Domérien basal) en Europe occidentale. Documents des Laboratoires de Géologie Lyon 98, 1-297.

Dommergues, J.-L. \& Bonnot, N. 2007. Présence en Bourgogne d'Epideroceras hugi Donovan, 1958, une ammonite rare du Sinémurien supérieur: ontogenèse, statut spécifique et parenté. Revue scientifique de Bourgogne 6, 76-84.

Dommergues, J.-L. \& Meister, C. 1990. Les faunes d'ammonites de l'Austroalpin Moyen dans les Alpes Rhétiques italiennes (région de Livigno); biostratigraphie et implications paléogéographiques. Revue Paléobiologie 9(2), 291-307.

Dommergues, J.-L. \& Meister, C. 1992. Late Sinemurian and Early Carixian ammonites in Europe with cladistic analysis of sutural characters. Neues Jahrbuch für Geologie und Paläontologie 185(2), 211-237.

Dommergues, J.-L. \& MeIster, C. 1999. Cladistic formalisation of relationships within a superfamily of lower Jurassic Am- 
monitina: Eoderocerataceae Spath, 1929. Revue de Paléobiologie 18(1), 273-286.

Dommergues, J.-L. \& Mouterde, R. 1980. Modalités d'installation et d'évolution des Harpocératinés (Ammonitina) au Domérien inférieur dans le Sud-Ouest de l'Europe (France, Portugal). Geobios 13(3), 289-325.

DOI 10.1016/S0016-6995(80)80075-1

Dommergues, J.-L. \& Mouterde, R. 1981. Les Acanthopleurocératinés portugais et leurs relations avec les formes subboréales. Ciências da Terra 6, 77-100.

Dommergues, J.-L., Meister, C. \& Mouterde, R. 1997. Pliensbachien, 15-23, 114-119. In GROUPE FRANÇAIS DU JURASSIQUE, CARiou et Hantzergue (ed.) Biostratigraphie du Jurassique ouest-européen et méditerranéen: zonations parallèles et distribution des invertébrés et microfossiles. Bulletin du Centre Recherche Elf, Exploration et Production, Mémoires 17.

Dommergues, J.-L., Meister, C. \& Neige, P. 2004a. Fuciniceras capilliolusitanicum nov. sp., une nouvelle espèce d'ammonite du Domérien lusitanien (Pliensbachien, Portugal). Revue de Paléobiologie 23(1), 373-386.

Dommergues, J.-L., Meister, C., Neige, P. \& Rocha, R.B. 2004b. Endemic Sinemurian (Early Jurassic) ammonites from the Lusitanian basin (Portugal). Revue de Paléobiologie 23(2), 529-549.

Dommergues, J.-L., Meister, C. \& Rocha, R.B. 2010. The Sinemurian ammonites of the Lusitanian Basin (Portugal): an example of complex endemic evolution. Paleodiversity 3, 59-87.

Donovan, D.T. 1990. The Late Sinemurian ammonite genus Vicinodiceras Trueman. Jubilé scientifique René Mouterde, 16 juillet 1990, Lyon. Les Cahiers de l'Université Catholique de Lyon, Série Sciences 4, 29-37.

Donovan, D.T. \& SuRLYK, F. 2003. Lower Jurassic (Pliensbachian) ammonites from Bornholm, Baltic Sea, Denmark. Geological Survey of Denmark and Greenland Bulletin 1, $555-583$.

DuArte, L.V. \& SoAres, A.F. 2002. Litostratigrafia das séries margo-calcárias do Jurássico inferior da Bacia Lusitânica (Portugal). Comunicações do Instituto Geologico e Mineiro 89, 135-154.

Duarte, L.V., Silva, R.L., Oliveira, L.C.V., Comas-Rengifo, M.J. \& Silva, F. 2010. Organic-Rich facies in the Sinemurian and Pliensbachian of the Lusitanian Basin, Portugal: Total organic carbon distribution and relation to transgressive-regressive facies cycles. Geologica Acta 8(3), 325-340.

EDmunds, M. 2009. A revision of the Lower Jurassic ammonite genus Eoderoceras Spath and its immediate descendants and other relatives. Monograph of the Palaeontological Society Publication 633, 1-89.

Edmunds, M., Varah, M. \& Bentley, A. 2003. The ammonite biostratigraphy of the Lower Lias "Armatum Bed" (upper Sinemurian-Lower Pliensbachian) at St Peter's Field, Radstock, Somerset. Proceedings of the Geologists' Association $114,65-96$.

Geczy, B. 1976. Les ammonites du Carixien de la montagne du Bakony. Akadémiai Kiado, 1-220.

GeCZY, B. 1998. Lower Pliensbachian ammonites of Villany (Hungary). Hantkeniana 2, 5-47.

Haug, E. 1908-1911. Traité de Géologie II. Les Périodes géo- logiques, livres 1-2, 539-1396. Librairie Armand Colin, Paris.

Hillebrandt, A. von 1987. Liassic Ammonite zones of South America and correlations with other Provinces. With description of new genera and species of ammonites, 111-157. In Volkheimer, W. (ed.) Bioestratigrafia de los Sistemas Regionales del Jurassico y Cretacico en America del Sur. Comité Sudamericano del Jurásico y Cretácico, Mendoza.

Hoffmann, K. 1982. Die stratigraphie, Paläogeographie und Ammonitenführung des Unter-Pliensbachium (Carixium, Lias gamma) in Nordwest-Deutschland. Geologisches Jahrbuch A 55, 3-439.

HousA, V. 1965. Sexual dimorphism and the system of Jurassic and Cretaceous Ammonoidea (Preliminary note). Časopis Národního muzea 134(7), 33-35.

Howarth, M.K. 2002. The Lower Lias of Robin Hood's Bay, Yorkshire, and the work of Leslie Bairstow. Bulletin of the Natural History Museum 58, 81-152.

Howarth, M.K. \& Donovan, D.T. 1964. Ammonites of the liassic family Juraphyllitidae in Britain. Palaeontology 7, 286-305.

Hyatт, A. 1867. The fossil Cephalopods of the Museum of Comparative Zoology. Bulletin of the Museum of Comparative Zoology 5, 71-102.

Hyatt, A. 1900. Cephalopoda, 502-604. In Zittel, K.A. von \& Eastman, C.R. (eds) Text-Book of Palaeontology. McMillan, London.

Joly, B. 2000. Les Juraphyllitidae, Phylloceratidae, Neophylloceratidae (Phyllocerataceae, Phylloceratina, Ammonoidea) de France au Jurassique et au Crétacé. Geobios, Mémoire spécial 23 \& Mémoires de la Société Géologique de France, nouvelle série 174, 1-202.

Meister, C. 1986. Les ammonites du Carixien des Causses (France). Mémoires suisses de Paléontologie 109, 1-209.

Meister, C. 1993. L'évolution paralèlle des Juraphyllitidae euroboréaux et téthysiens au Pliensbachien: le rôle des contraintes internes et externes. Lethaia 26, 123-132.

Meister, C. 2010. Worldwide ammonite correlation at the Pliensbachian Stage and Substage boundaries (Lower Jurassic). Stratigraphy 7(1), 83-101.

Meister, C., Aberhan, M., Blau, J., Dommergues, J.-L., FeistBurkhardt, S., Hailwood, E.A., Hart, M., Hesselbo, S.P., Hounslow, M.H., Hylton, M., Morton, N., Page, K. \& PrICE, G. 2006. The Global Boundary Stratotype Section and Point (GSSP) for the base of the Pliensbachian Stage (Lower Jurassic), Wine Haven, Yorkshire, UK. Episodes 29(2), 93-106.

Meister, C., Blau, J., Dommergues, J.-L., Feist-Burkhardt, S., Hart, M., Hesselbo, S.P., Hylton, M., Page, K. \& Price, G. 2003. A proposal for the Global Boundary Stratotype Section and Point (GSSP) for the base of the Pliensbachian Stage (Lower Jurassic). Eclogae Geologicae Helvetiae 96, 275-297.

Mouterde, R. 1947. Le Lias moyen de São Pedro de Muel (Portugal). Comptes-rendus sommaires de la Société géologique de France, séance du 21 avril 1947, 137-138.

Mouterde, R. 1951. Ammonites du Lias moyen portugais. Boletin da Sociedade Geológica de Portugal 9(3), 175-190. 
Mouterde, R. 1967a. Le Lias Moyen de São Pedro de Muel (Portugal). (Première partie). Comunicações dos Serviços Geológicos de Portugal 52, 185-208.

Mouterde, R. 1967b. Le Lias du Portugal vue d'ensemble et division en Zones. Comunicações dos Serviços Geológicos de Portugal 52, 209-225.

Mouterde, R. 1970. 1. Céphalopodes, 39-74. In Mouterde, R. \& Ruget, C. Le Lias Moyen de São Pedro de Muel (Portugal), Deuxième partie: Paléontologie. Comunicações dos Serviços Geológicos de Portugal 54.

Mouterde, R., Rocha, R.B. \& Delance, J. 1981. Atlas des fossiles caractéristiques du Lias portugais, 1 - Lias inférieur. Ciências da Terra 6, 49-76.

Mouterde, R., Rocha, R.B. \& Ruget, C. 1978. Stratigraphie et faune du Lias et de la base du Dogger au Nord du Mondego (Quiaios et Brenha). Comunicações dos Serviços Geológicos de Portugal 63, 83-104.

Mouterde, R., Dommergues, J.-L. \& Rocha, R.B. 1983. Atlas des fossiles caractéristiques du Lias portugais, 2 - Carixien. Ciências da Terra 7, 187-254.

Mouterde, R., Dommergues, J.-L., Meister, C. \& Rocha, R.B. 2007. Atlas des fossiles caractéristiques du Lias portugais, 3 Domérien (Ammonites). Ciências da Terra 16, 67-111.

PhelPS, M. 1985. A refined ammonite biostratigraphy for the Middle and Upper Carixian (ibex and davoei zones, Lower Jurassic) in North-West Europe and stratigraphical details of the Carixian-Domerian boundary. Geobios 18(3), 321-362. DOI 10.1016/S0016-6995(85)80098-X

POMPECKJ, J.F. 1897. Neue Ammonniten aus dem unteren Lias von Portugal. Zeitschrift der Deutschen geologischen Gesellschaft 49, 636-661.

PompeckJ, J.F. 1898. Notes sur quelques ammonites du Sinémurien du Portugal. Communicações de Direcção de Trabalhos Geológicos de Portugal 3(2), 210-238.

Quenstedt, F.A. 1845-1849. Petrefactenkunde Deutschlands; Die Cephalopoden. 580 pp. L.F. Fues, Tübingen.

Quenstedt, F.A. 1882-1885. Die Ammoniten des Schwäbischen Jura. 1440 pp. E. Schweizerbart Verlag, Stuttgart.

RulleAu, L. 1998. Géologie et paléontologie du Trias et du Lias inférieur et moyen de la région lyonnaise. $12 \mathrm{pp}$. Section géologie-paléontologie du C.E. des Ciments Lafarge France, Usine du Val d'Azergues.

SAndness, F. \& PAcheCo, J. 2002. Portuguese deepwater basins show potential. Offshore 62, 1-3.
Schlatter, R. 1980. Biostratigraphie und Ammonitenfauna des Unter-Pliensbachium im Typusgebiet (Pliensbach, Holzmaden und Nürtingen, Württemberg, Südwestdeutschland). Stuttgarter Beiträge zur Naturkunde B 65, 1-261.

Schlatter, R. 1991. Biostratigraphie und Ammonitenfauna des Ober-Lotharingium und Unter-Pliensbachium im Klettgau (Kanton Schaffausen, Schweiz) und angrenzender Gebiete. Mémoires suisses de Paléontologie 113, 1-133.

SCHLEGElmilch, R. 1992. Die Ammoniten des süddeutschen Lias. 241 pp. Gustav Fischer, Auflage 2, Stuttgart.

Schubert, S. 2007. Fossilienfunde im Unter-Pliensbachium (Carixium) am neuen Autobahnzubringer bei Herford. Bericht des Naturwissenschaftlichen Verein für Bielefeld und Umgegend 47, 17-93.

Simpson, M. 1855. The Fossils of the Yorkshire Lias. 149 pp. Whitby, London.

Spath, L.F. 1926. Notes on Yorkshire ammonites. The Naturalist 1926, 45-49, 137-140, 169-171, 201-206, 265-268.

Spath, L.F. 1929. Corrections of cephalopod nomenclature. The Naturalist 1929, 269-271.

Spath, L.F. 1938. A catalogue of the ammonites of the Liassic family Liparoceratidae in the British Museum (Natural History). 191 pp. British Museum of Natural History, London.

Srivastava, S.P. \& VerhoEF, J. 1992. Evolution of Mesozoic sedimentary basins around the North Central Atlantic: a preliminary plate kinematic solution, 397-420. In PARnell, J. (ed.) Basins of the Atlantic Seaboard: Petroleum geology, sedimentology and basin evolution. Geological Society of London, Special Publication 62.

ThIERry, J. et al. (40 co-authors) 2000. Late Sinemurian (193-191 Ma). In Dercourt, J., Gaetani, M., Vrielinck, B., Barrier, E., Biju-Duval, B., Bruner, M.F., Cadet, J.P., Crasquin, S. \& Sandulescu, M. (eds) Atlas Peri-Tethys, Palaeogeographical maps. CCGM/CGMW, Paris, map no. 7.

Trueman, A.E. 1919. The evolution of the Liparoceratidae. Quarterly Journal of the Geological Society of London 74, 247-298. DOI 10.1144/GSL.JGS.1918.074.01-04.11

Venturi, F., Nannarone, C. \& Bilotta, M. 2005. Early Pliensbachian ammonites from the Furlo Pass (Marche, Italy): two new faunas for the middle-western Tethys. Bollettino della Società Paleontologica Italiana 44(2), 81-115.

Zittel, C.A. von 1884. Cephalopoda. In Handbuch der Paläontologie. 893 pp. Druck und Verlag von R. Oldenbourg, München \& Leipzig. 